\title{
Islamic Finance, Consumer Protection and Public Policy
}

Faisal Kutty

\section{INTRODUCTION}

In a complaint filed against me years ago with the Law Society of Upper Canada (LSUC) (now renamed the Law Society of Ontario), the professional governing body of lawyers in Ontario, a client stated: "What this lawyer had me engage in is akin to me committing incest with my mother." The complaint arose from an "Islamic mortgage," the closing and registration of which had been facilitated by my office. Essentially an Islamic finance company, UM Financial ("UM"), had advanced the funds

1 "There are seventy-two types of riba, the least of which is like a man committing incest with his mother." Narrated by al-Tabaraani in al-Awsat, classified as saheeh by al-Albaani in Saheeh al-Jaami', no. 3537; See also Farooq, Mohammad Omar. December 27, 2009. "Riba, Interest and Six Hadiths: Do We Have a Definition or a Conundrum?" Review of Islamic Economics 13(1), 105-141; Farooq argues that this hadith used to expand the term riba to include all forms of interest does not hold up.

F. Kutty $(\bowtie)$

Dwayne O. Andreas School of Law, Barry University, Orlando, FL, USA

e-mail: fkutty@barry.edu

(C) The Author(s) 2020

T. Akram and S. Rashid (eds.), Faith, Finance, and Economy, https://doi.org/10.1007/978-3-030-38784-6_7 
to close a house purchase. UM claimed to have structured the transaction as a diminishing musharaka. ${ }^{2}$ My role was to ensure that the homebuyers, a couple, received clear title to the house being purchased and the investor (lender), in this case the Islamic finance company, UM, had security for their "Islamic loan." As part of the transaction, my office had the homebuyer clients sign standard real estate closing documents as well as documents governing and structuring the relationship between UM and the homebuyers. ${ }^{3}$ As is typical in such transactions, I was on a joint retainer for UM and the homebuyers.

Following the registration of the transaction, one of the buyers more thoroughly studied the documents and the structure, all of which were developed and prepared by UM. He concluded that the transaction was not "Islamic" or "Shari'ah-compliant."

Because my client's attempts to have the situation addressed by UM were unsuccessful, he filed a complaint against me with the LSUC. He was persistent and adamant in his position. He apparently harassed the LSUC non-stop, including showing up in person at its offices and essentially refusing to leave the premises unless it addressed the complaint. He also reportedly quoted to its members the hadith mentioned in footnote one.

The LSUC responded by dispatching its chief investigation counsel and a forensic auditor to deliver the complaint notice to me personally. ${ }^{4}$ Its members were obviously concerned, and I spent some time educating them about Islamic finance in my boardroom. The complaint was eventually dismissed with the direction that going forward I had to advise my clients that I was not providing them with "Islamic finance" or "Shari'ahcompliance" advise. ${ }^{5}$

${ }^{2} \mathrm{~A}$ diminishing musharakah is a diminishing partnership.

In a diminishing partnership (also known as a "declining balance partnership" or "declining musharakab"), one partner's share is drawn down while it is transferred to another partner until the entire sum is passed over. Such a structure is common in homebuying where the lender (generally a bank) buys a property and receives payment from a buyer (via monthly rent payments) until the whole balance is paid off.

For more information, see Musharakah, https://www.investopedia.com/terms/m/ musharakah.asp\#ixzz5Yq5Mbfzd.

${ }^{3}$ In a conventional mortgage transaction, our office would have prepared standard real estate documents and the bank's documents.

${ }^{4}$ Other lawyers with whom I spoke at the time were shocked to learn that the Law Society officials showed up in person.

5 There is also the related issue that lawyers are not insured to provide non-legal advice. 
This incident illustrates a number of issues, but for the purposes of this chapter, I will focus on the following:

1. The importance of faith or religion for some people when it comes to financial decisions; and

2 . The potential consumer protection concerns with respect to regulating what is or what is not "Islamic" or "Shari'ah-compliant" in western financial markets.

These two issues run as the central themes through the discussion in this paper. This chapter is organized into four parts. Part I provides an overview of the origins, sources, and history of Islamic finance. Part II provides an introduction to the basic principles of Islamic finance. Part III touches upon some of the regulatory and policy concerns and issues. Part IV concludes with some observations about future prospects and recommendations.

\section{Origins, Sources ANd Brief History}

My client's complaint centered around the concern that the loan he negotiated, and that my office had helped him finalize, was not consistent with Islamic finance rules. Islamic finance rules evolved out of Islamic economics, which in turn takes its inspiration from the Shari'ah. ${ }^{6}$ The Islamic financial system is based on religious teachings that emphasize that everything belongs to God and that human beings are accountable to God for their conduct (and intentions) on earth. Human beings have been tasked to be trustees over God's wealth and must discharge this role within a framework that prioritizes, among other things, social and economic justice. The ethical, moral, social, and legal principles at the core of Islamic finance are derived from the Shari'ah (loosely and inaccurately referred to as Islamic law). ${ }^{7}$ It essentially involves balancing the material

\footnotetext{
${ }^{6}$ Shari'ah and Islamic law will be used throughout the paper though the two do not necessarily have the same meaning. Some writers inaccurately use them interchangeably. Kutty, Faisal. 2010. "The Myth and Reality of 'Shari'a Courts' in Canada: A Delayed Opportunity for the Indigenization of Islamic Legal Rulings." University of St. Thomas Law Journal 7, 559.

${ }^{7}$ For an explanation of Shari'ah, see Kamali, M.H. 1989. "Source, Nature and Objectives of Shari'ah." Islamic Quarterly 33, 211-233; Part 5 of Kutty, Faisal. 2010. "The
} 
and the spiritual as well as the individual and collective interests within a God-centered ethical framework.

The Islamic finance system seeks to provide banking and finance services that comply with Islamic principles. ${ }^{8}$ It must operate within ethical and religious constraints, but it should also further social and economic justice. By complying with Islamic principles, the Islamic finance system aims to achieve a more equitable distribution of wealth and income, and it encourages full employment, socioeconomic justice, and stability. ${ }^{9}$ In essence, it can be described as a modified free enterprise system that locates itself in the middle of the spectrum between socialism and capitalism.

Islamic finance, in its broadest sense, has existed since the early years of Islam, starting with the social and economic justice teachings of the Prophet Muhammad (Peace be upon him-[pbuh]) ${ }^{10}$ as detailed in the Quran and Sunnah (teachings and sayings attributed to the Prophet). ${ }^{11}$ Islam teaches that it is the continuation and culmination of the messages sent to previous prophets and messengers. Consistent with this view, at its core many of the central teachings and beliefs in Islam, including teachings on social and economic justice, are very similar to those of other major religious traditions. Historians of early Islamic civilization have documented that banking activities similar to those performed today took

Myth and Reality of 'Shari'a Courts' in Canada: A Delayed Opportunity for the Indigenization of Islamic Legal Rulings," University of St. Thomas Law Journal 7, 559; see also Kutty, Faisal. September 24, 2014. "The Kutty 'Islamic Law' Flowchart," http://www. islamiclawflowchart/.

${ }^{8}$ Maljichi, Drita N. 2014. "Islamic Financial Markets and Institutions." Vizione 21, 291-292; Shaikh, Salman Ahmed. January 14, 2010. "A Brief Review \& Introduction to Practiced Islamic Banking \& Finance." Retrieved from https://ssrn.com/abstract= 1536943 or http://dx.doi.org/10.2139/ssrn.1536943; El-Gamal, Mahmoud A. 2006. Islamic Finance: Law, Economics and Practice. Cambridge: Cambridge University Press.

${ }^{9}$ El-Ghattis, Nedal. "Islamic Banking's Role in Economic Development: Future Outlook." Retrieved from https://pdfs.semanticscholar.org/cfc6/ 6f09435a5445c2cadd2d18937823635c5d3d.pdf; Iqbal, Zamir and Mirakhor, Abbas. 2011. An Introduction to Islamic Finance: Theory and Practice, 2nd ed. Asia: Wiley.

${ }^{10}$ Peace be upon him (pbuh) is a term customarily used when referring to the Prophet Muhammad.

${ }^{11}$ El-Gamal, Mahmoud A. 2006. Islamic Finance: Law, Economics and Practice. Cambridge: Cambridge University Press; Reda, Ayman. 2018. Prophecy, Piety, and Profits: A Conceptual and Comparative History of Islamic Economic Thought. New York: Palgrave Macmillan. 
place from the early days of Islamic civilization. ${ }^{12}$ In fact, the Islamic empire had a well-developed financial system, complete with a legislative system governing transactions, a judicial system enforcing contracts, different commercial papers and banknotes, and licensed bankers, which contributed to the development of modern banking practices. ${ }^{13} \mathrm{How}^{-}$ ever, under the influence of European colonizers, many Islamic countries adopted Western banking models in the nineteenth century. It was not until the mid-twentieth century that Islamic financial institutions began to reemerge, partly driven by political Islam and a renewed sense of Islamic identity. ${ }^{14}$ Since then, the global market for Islamic finance has become one of the fastest-growing segments of global finance with a growth rate between 10-12\% annually and a "Shari'ah-compliant" industry worth well over \$2 trillion USD in 2015 and projected to grow to $\$ 3.2$ trillion by 2020 according to Thomson Reuters. ${ }^{15}$

Once largely limited to the Middle East and Southeast Asia, "Shari'ahcompliant" finance and products are gaining attention outside these traditional markets. It made its first appearance in the West in 1978 with

12 Alharbi, Ahmad. 2016. "Development of Islamic Finance in Europe and North America: Opportunities and Challenges." International Journal of Islamic Economics and Finance Studies 2(3), 109-110; Udovitch, A. 1979. "Bankers Without Banks: Commerce, Banking and Society in the Islamic World of the Middle-Ages." In The Dawn of Modern Banking (ed.) by the Centre for Medieval and Renaissance Studies, Los Angeles: University of California; Al-Hamdani, Khaled. 2000. al-Nizam al-Masrafi fi al-Dawlah al-Islamiyah (The Banking System in the Islamic State); Islamiyat al-Maarifa, Winter, pp. 15-41; Labib, S. March 1969. "Capitalism in Medieval Islam." Journal of Economic History 29(1), 79-140; Issawi, C. 1966. The Economic History of the Middle East 18001914. Chicago: University of Chicago Press; Chachi, Abdelkader. 2005 A.D/1426 A.H. "Origin and Development of Commercial and Islamic Banking Operations." Journal of King Abdulaziz University: Islamic Economics 18(2), 3-25.

13 Ibid.

${ }^{14}$ Alharbi, Ahmad. 2016. "Development of Islamic Finance in Europe and North America: Opportunities and Challenges." International Journal of Islamic Economics and Finance Studies 2(3), 112; Zaman, Arshad. 2011. "Sayyid Abu'l A'la Maududi on Islamic Economics: A Review Article." Islamic Studies, 50(3-4), 303-323. Retrieved from https://ssrn.com/abstract=2225711; Kuran, Timur. 2004. Islam and Mammon: The Economic Predicaments of Islamism. Princeton: Princeton University Press.

15 Thomson Reuters. 2015. Canada Islamic Finance Outlook 2016 at 58, http://www. tfsa.ca/storage/reports/Canada_Islamic_Finance_2016.pdf. See also Staff Writer. August 7, 2016. "Islamic Finance Assets Forecast to be Worth $\$ 3.2 \operatorname{trn}$ by 2020." Arabian Business, https://www.arabianbusiness.com/islamic-finance-assets-forecast-be-worth3-2trn-by-2020-641156.html. 
the establishment of the Islamic Finance House Universal Holding S.A. in Luxembourg. ${ }^{16}$ Today London has a significant presence in Islamic Finance. ${ }^{17}$

North America, considered to have one of the most stable banking systems in the world, has also witnessed growing interest in Islamic finance. 18 "Shari'ah-compliant" products have been offered in Canada and the United States since the 1980s. ${ }^{19}$ The significant, relatively affluent, and religiously observant Muslim population in North America represents a substantial consumer market for investments, pensions, insurance, mortgages, and commercial businesses, as along with day-to-day banking. Islamic finance only began to get real traction in the United States in 1990s, when "the New York branch of the United Bank of Kuwait obtained two interpretive letters issued by the Office of the Comptroller of the Currency to offer Islamic retail banking services in the country." 20 The first letter, issued in 1997, permitted the use of ijarah, ${ }^{21}$ whereby the bank would act as a "riskless principal," buying real estate at the request of the lessee, then leasing it back to them until the final payment, at which time the lessee would be given title. ${ }^{22}$ The second letter, issued in 1999, allowed murabaha-based financial products. As in the previous

${ }^{16}$ European Central Bank (Occasional Paper Series, No. 146, June 2013), "Islamic Finance in Europe." Retrieved from https://www.ecb.europa.eu/pub/pdf/scpops/ ecbocpl46.pdf; Alharbi, Ahmad. 2016. "Development of Islamic Finance in Europe and North America: Opportunities and Challenges." International Journal of Islamic Economics and Finance Studies 2(3), 112; di Mauro, Filippo, Caristi, Pierluigi, Couderc, Stéphane, Di Maria, Angela, Ho, Lauren, Kaur Grewal, Baljeet, Masciantonio, Sergio, Ongena, Steven R.G., Zaheer, Sajjad. April 15, 2013. "Islamic Finance in Europe." ECB Occasional Paper No. 146. Retrieved from SSRN: https://ssrn.com/abstract=2251204.

${ }^{17}$ Langah, Waseem Ahmad. February 25, 2009. Islamic Banking in the UK: Challenges and Opportunities. Retrieved from https://ssrn.com/abstract=1349170.

${ }^{18}$ Alharbi, Ahmad. 2016. "Development of Islamic Finance in Europe and North America: Opportunities and Challenges." International Journal of Islamic Economics and Finance Studies 2(3), 112; Thomson Reuters. 2015. Canada Islamic Finance Outlook 2016 at 58, http://www.tfsa.ca/storage/reports/Canada_Islamic_Finance_2016.pdf.

${ }^{19}$ Ibid. at 124 .

${ }^{20}$ Ibid.

${ }^{21}$ See discussion below.

${ }^{22}$ Alharbi, Ahmad. 2016. "Development of Islamic Finance in Europe and North America: Opportunities and Challenges." International Journal of Islamic Economics and Finance Studies 2(3), 124-125. 
scheme, the bank had to act again as a "riskless principal," thereby permitting the activity. While the bank ceased operations in the United States in 2000, it bought and leased sixty homes for American Muslims. ${ }^{23}$ Since 2000, many small Islamic financial institutions have entered the market, and many conventional financial institutions have begun to offer Islamic products with varying degrees of compliance with Islamic principles. ${ }^{24}$

Islamic finance is also gaining interest in Canada and is expected to increase as Canada has a large, growing, young, and observant Muslim population. ${ }^{25}$ The 2011 National Household Survey found Muslims make up $3.2 \%$ of Canada's population. ${ }^{26}$ The community is expected to reach $6.6 \%$ by $2030 .{ }^{27}$ While some Islamic financial products are available, no major financial institution has successfully marketed any "Shari'ah-compliant" products or services. ${ }^{28}$ The first Islamic financial body in Canada - the Islamic Co-operative Housing Corporation Ltd., a grassroots, community-based project-was established in Toronto in 1979.29 Since then, several other Islamic financial institutions have been established throughout Ontario and Quebec. One such company, UM Financial, founded in 2004, became one of the primary Islamic financial providers in Canada. It partnered with Central 1 Credit Union of Canada and marketed "Islamic mortgages." From 2006 to 2007, UM Financial provided $\$ 86.1$ million in home financing. The company was essentially relabeling, using legal fictions/assignments, drafting parallel documents, and clouding disclosure to unsophisticated buyers.

\footnotetext{
23 Ibid. at 125 .

24 Ibid. at 126.

25 Ibid.

${ }^{26}$ Statistics Canada. 1991. 2011 National Household Survey: Data Tables, 99-010X2011032. Ottawa.

27 Ibid.

28 Ibid.

${ }^{29}$ Khan, Sheema. April 7, 2008. "It's Time to Take Interest in Islamic Financing." The Globe and Mail, https://www.theglobeandmail.com/opinion/its-time-to-takeinterest-in-islamic-financing/article22501330/; see also http://www.ansarhousing.com/ about_us.aspx.
} 
The company declared bankruptcy in 2011, and its founder and chief Shari'ah advisor were charged with fraud. ${ }^{30}$

The fact remains that there is a growing appetite for Islamic finance products even in North America. Inevitably, there will be unscrupulous actors who prey on the lack of knowledge among consumers both of finance and Islamic principles, non-existence of religious standards or regulatory bodies, lack of government oversight and issues and obstacles in structuring "Shari'ah-compliant" products and transactions.

\section{Introduction to the Principles of Islamic Finance}

Islamic finance is differentiated from conventional finance by the fact that Islamic finance is God-centered and informed by principles of Islamic law.

\section{Probibitions}

Islamic finance has become synonymous with a system that, at its core, prohibits: (1) usury (riba); (2) taking excessive or unnecessary risk or gambling where one party benefits only due to the loss of the other (qimar and maysir); (3) uncertain transactions/speculation (gharar); and (4) the limitation in dealing with products, industries and services considered prohibited ( haram), such as alcohol, gambling, illegal drugs, certain weapons, pornography, and other areas deemed harmful to society or the individual, etc.

\section{Riba ("Usury")}

For most people aware of Islamic finance, the first thing that comes to mind is the prohibition of riba, which is understood by most Muslims as interest per se. The basis for this prohibition of riba is said to be rooted in

${ }^{30} \mathrm{Ha}$, Tu Thanh. 2014. "RCMP charge missing Toronto Financier with \$4.3Million Mortgage Fraud." The Globe and Mail, https://www.theglobeandmail.com/ news/national/rcmp-charge-missing-toronto-financier-with-43-million-mortgage-fraud/ article16972349/; Nasser, Shanifa. 2017. "Muslim Mortgage Kingpin Led Investigators on 'Treasure Hunt' for Missing Gold: Crown.” CBC News, https://www.cbc.ca/ news/canada/toronto/omar-kalair-muslim-madoff-shariah-mortgages-1.4390002; Pasha, Shaheen and French, Cameron. 2011. "Canada Bankruptcy May Hurt Islamic Finance in N. America." Reuters, https://www.reuters.com/article/canada-islamic-bankruptcyidUSL5E7MT3KY20111205. 
the Quran and the teachings of the Prophet Muhammad (peace be upon him), the Sunnah. Contrary to the understanding of most Muslims, the definition of riba has been contested and evolving throughout Islamic history and is often the subject of intense debate among Islamic jurists, scholars, and bankers. ${ }^{31}$ A conservative/orthodox understanding, which is the majority view, holds that the term applies to any form of interest and precludes its payment or collection. ${ }^{32}$ A minority, but growing, interpretation opines that riba refers to "usury" or excessive compounded interest. ${ }^{33}$ The two underlying principles that are used as the basis to prohibit riba are the Quran's ${ }^{34}$ stipulation that only active trading serves as the basis for increasing wealth and the unfairness of manipulating desperate "poorer members of society by unscrupulous merchants." 35 The prohibition and the principles behind riba have historically been central tenets of

${ }^{31}$ Azhar, Rauf. November 15, 2009. Economies of an Islamic Economy, Themes in Islamic Studies, Vol. 6, https://doi.org/10.1163/ej.9789004179370.i-470; Fadel, Mohammad Riba. Forthcoming. "Efficiency, and Prudential Regulation: Preliminary Thoughts," Wisconsin International Law Journal 25(4), 656; Islamic Law and Law of the Muslim World Paper No. 08-18; El-Gamal, Mahmoud A. 2003. "Interest' and the Paradox of Contemporary Islamic Law and Finance." Fordham International Law Journal 27(1), Article 6, https://pdfs.semanticscholar.org/8cb7/0cc8baaf91 lad52f932205al722f76e3f049.pdf; Karasik, Theodore, Wehrey, Frederic, and Strom, Steven. 2006. "Islamic Finance in a Global Context: Opportunities and Challenges." Chicago Journal of International Law $7(2), 379$.

${ }^{32}$ Kuran, Timur. 2004. Islam and Mammon: The Economic Predicaments of Islamism. Princeton: Princeton University Press; Farooq, Mohammad Omar. 2007. "Stipulation of Excess in Understanding and Misunderstanding Riba: The Al-Jassas Link." Arab Law Quarterly 21(4), 285-316.

${ }^{33}$ Arberry, Arthur John. 1996. The Koran Interpreted: A Translation. New York: Simon and Schuster; Kuran, Timur. 2004. Islam and Mammon: The Economic Predicaments of Islamism. Princeton: Princeton University Press; Farooq, Mohammad Omar. 2007. "Stipulation of Excess in Understanding and Misunderstanding Riba: The Al-Jassas Link." Arab Law Quarterly 21(4), 285-316.

${ }^{34}$ The verses against interest ( $r i b a$ ) can be found in the Surah Al-Baqara chapter, verses 275-280, the Al-Rom chapter, verse 39, and the AI-Nisa chapter, verses 159-160; e.g. "Those who swallow usury cannot arise except as he arises whom the devil prostrates by (his) touch. That is because they say trading is like usury. And Allah has allowed trading and forbidden usury" (Quran, 2.275).

${ }^{35}$ See Aziz, Zeti A. 2008. "Enhancing Interlinkages and Opportunities: The Role of Islamic Finance." Islamic Finance: Global Trends and Challenges 18, 5-7; National Bureau of Asian Research ed. (quantifying annual growth rate of Islamic finance at fifteen to twenty percent). 
several major religions (e.g., Judaism ${ }^{36}$ and Christianity ${ }^{37}$ ). According to some observers, around 1000 A.D. there existed little difference between Christian Europe and the territories under Muslim rule pertaining to their attitudes toward interest. ${ }^{38}$ Indeed, the Catholic Church lifted the ban on interest only in the mid-nineteenth century. ${ }^{39}$ Moreover, there are banks in Israel that cater to Jews who refuse to pay or take interest. ${ }^{40}$

\title{
Qimar ("Excessive Risks") and Maysir ("Wagering”)
}

Transactions or dealings that involve unnecessarily or unreasonably risky undertakings in the hopes of achieving something are also prohibited. ${ }^{41}$ This includes qimar, which literally means betting and wagering. ${ }^{42}$ Qimar refers to taking ownership of something valuable ( $m a l)$ through

\begin{abstract}
${ }^{36}$ In Judaism, interest was prohibited as per the following: "If you lend money to any of My people with you who is poor, you shall be to him as a creditor, and you shall not exact interest from him" (Ex. 22:25); "He that hath not given this money upon usury; nor taken reward against the innocent. He that doeth these things: shall never fall" (Psalm 15); "To a foreigner you may lend upon interest, but to your brother you shall not" (Deut. 23.19); See Reda, Ayman. 2018. Prophecy, Piety, and Profits: A Conceptual and Comparative History of Islamic Economic Thought, New York: Palgrave Macmillan. (Jews, Christians, etc.); see also Ahmad, Shaikh Mahmud. 1981. "Judaism and Interest." Islamic Studies 20(1), 47-82.

${ }^{37}$ In Christianity, it is discouraged per the following: "Love your Enemies and Do Good, Lend, Expect Nothing in Return" (Luke 6:35); See Reda, Ayman. 2018. Prophecy, Piety, and Profits: A Conceptual and Comparative History of Islamic Economic Thought. New York: Palgrave Macmillan (jews, Christians, etc.); see also Mayyasi, Alex. 2017. "Of Money and Morals." Aeon. Retrieved from https://aeon.co/essays/how-did-usury-stopbeing-a-sin-and-become-respectable-finance.
\end{abstract}

${ }^{38}$ Schoon, Natalie and Nuri, Julinda. 2012. "Comparative Financial Systems in Judaism, Christianity and Islam: The Case of Interest." Retrieved from https://ssrn.com/abstract= 2126503 or http://dx.doi.org/10.2139/ssrn.2126503.

${ }^{39}$ Weber, Max. 1979. Economy and Society. Berkeley, CA: University of California Press.

${ }^{40}$ Seznec, Jean-François. 1999. "Ethics, Islamic Banking and the Global Financial Market." Fletcher Forum of World Affairs 23(1), 161.

${ }^{41}$ Uddin, Md Akther. 2015. Principles of Islamic Finance: Prohibition of Riba, Gharar and Maysir. Kuala Lumpur, Malaysia: INCEIF, https://mpra.ub.uni-muenchen. de/67711/1/MPRA_paper_67711.pdf; Abdullah, Atikullah Hj. 2013. "The Elements of Qimar (Wagering) and Gharar (Uncertainty) in the Contract of Insurance Revisited," https://ibtra.com/pdf/journal/v9_n2_article5.pdf.

42 Ibid. 
some form of wager. ${ }^{43}$ Islamic law unequivocally prohibits every zero-sum scenario through wagering on very risky outcomes.

This prohibition also extends beyond qimar to maysir, which is broader and extends to all kinds of gambling and games of chance. ${ }^{44}$ Evolving out of the pre-Islamic practice of divining arrows whereby seven persons gambled for shares (portions) of an allotted prize, the objection is to the fact that the agreement between the players is based entirely on wishful odds that have no real statistical probability.

In essence, these prohibitions aim at preluding "effortless gain" generated from any dealings." 45 It is quite obvious that there will be a wide range of diverse opinions on what would or would not fall into these categories.

\section{Gharar ("Probibition on Excessive Risk and Deception")}

Another central pillar of Islamic finance is the prohibition of excessive risk, uncertainty and deception all grouped under the heading of gharar. ${ }^{46}$ Obviously, business and investment always involve elements of risk, but disproportionate uncertainty or risk would violate Islamic principles. This of course rules out speculative trading. According to Muhammad Ayub, Islamic jurists have defined gharar as "the sale of a thing which is not present at hand, or the sale of a thing whose aqibab (consequence) is not known, or a sale involving hazard in which one does not know whether it will come to be or not." 47 The prohibition against gharar tends to prohibit major financial products, according to most but not all Islamic finance scholars, such as "forward contracts, swap agreements, hedges,

43 Ibid.

44 Ibid.

${ }^{45}$ Nizami, Shah M. 2011. "Islamic Finance: The United Kingdom's Drive to Become the Global Islamic Finance Hub and the United States' Irrational Indifference to Islamic Finance." Suffolk Transnational Law Review, 34(1), 219.

${ }^{46}$ Uddin, Md Akther. 2015. Principles of Islamic Finance: Prohibition of Riba, Gharar and Maysir. Kuala Lumpur, Malaysia: INCEIF, https://mpra.ub.uni-muenchen. de/67711/1/MPRA_paper_67711.pdf; Abdullah, Atikullah Hj. 2013. "The Elements of Qimar (Wagering) and Gharar (Uncertainty) in the Contract of Insurance Revisited," https://ibtra.com/pdf/journal/v9_n2_article5.pdf.

${ }^{47}$ Ayub, Muhammad. 2007. Understanding Islamic Finance, 58. West Sussex: Wiley. Retrieved 30 August 2018. 
options, derivatives, and financial insurance." ${ }^{28}$ It also prohibits the sale of things that do not yet exist, which some scholars have interpreted to include, for example, fish that a fishing boat setting out to sea may catch on its expedition, a crop that has yet to be planted, and even an unborn animal. $^{49}$

\section{Haram ("Probibited") Goods and Services}

Another dictate is that Islamic financial institutions must not be involved in areas prohibited by Islamic law, such as alcohol, tobacco, pork, gambling, pornography, and weapons. ${ }^{50}$ The degree in kind and level to which these are adhered to depend on the philosophy and strictness of the scholar or Shari'ah body, which may range from absolute prohibition to those who allow it to within a de-minimis threshold. Some of these prohibitions, to varying degrees, are similar to those found in the socially responsible investing (SRI) movement within conventional banking. ${ }^{51}$ In fact, in this context there may be some similarities between conventional

${ }^{48}$ Nizami, Shah M. 2011. “Islamic Finance: The United Kingdom's Drive to Become the Global Islamic Finance Hub and the United States' Irrational Indifference to Islamic Finance." Suffolk Transnational Law Review 34(1), 219; See also Richardson, Christopher F. 2006. "Islamic Finance Opportunities in the Oil and Gas Sector: An Introduction to an Emerging Field." Texas International Law Journal 42, 119-123; Nehad, A. and Khanfar, A. 2016. "A Critical Analysis of the Concept of Gharar in Islamic Financial Contracts: Different Perspectives." Journal of Economic Cooperation and Development 37(1), 1-24, http:/ /www.sesric.org/pdf.php?file=ART14103001-2.pdf.

${ }^{49}$ Nehad, A. and Khanfar, A. 2016. "A Critical Analysis of the Concept of Gharar in Islamic Financial Contracts: Different Perspectives." Journal of Economic Cooperation and Development 37(1), 1-24, http://www.sesric.org/pdf.php?file=ART14103001-2.pdf.

Waemustafa, W. 2015. "Theory of Gharar and Its Interpretation of Risk and Uncertainty from the Perspectives of Authentic Hadith and the Holy Quran: Review of Literatures," http://repo.uum.edu.my/18860/1/Wae_gharar.pdf.

${ }^{50}$ Jamaldeen, Faleel. "Seven Prohibited Industries in Islamic Financial Investments," https://www.dummies.com/personal-finance/islamic-finance/seven-prohibited-industriesin-islamic-financial-investments/; El-Gamal, Mahmoud A. 2006. Islamic Finance: Law, Economics and Practice. Cambridge: Cambridge University Press.

${ }^{51}$ Hayat, Usman. 2013. "Islamic Finance and Socially Responsible Investing." CFA Institute News, https://www.cfainstitute.org/-/media/documents/article/cfa-magazine/ 2013/cfm-v24-n2-2.ashx; Ferruelo, Elizabeth. 2012. "Why Socially Responsible Investing and Islamic Finance is on the Rise." Forbes, https://www.forbes.com/sites/ ashoka/2012/11/01/why-there-is-high-growth-potential-in-the-nexus-between-sociallyresponsible-investing-and-islamic-finance/\#5813dab0e3fl. 
and Islamic finance. Particularly, since the financial crisis of 2008, there has been pressure within Western countries for banking to become simpler, less reliant on highly leveraged capital structures, and for a more deeply ingrained sense of ethics. ${ }^{52}$

\section{Islamic Finance Products and Mechanisms}

The foregoing restrictions do not mean that Islamic finance is averse to business or taking calculated and reasonable risks to generate a profit. On the contrary, Islam is understood to encourage trade and the productive use of capital. ${ }^{53}$ As a result of these restrictions around riba, qimar/maisir, gharar, and the prohibition on engaging with haram goods and services, Islamic financial institutions have had to devise products and services that work around these "impediments" while generating profits. One of the fundamental conceptual shifts induced by Islamic finance is that transactions must be linked to assets using equity-based instruments and contracts as opposed to debt-based instruments. It also means that, at least in theory, there ought to be more emphasis on social justice, fairness, and ethical concerns. Provided that it is equity-based and avoids the above prohibitions, profits can be generated through the reallocation and management of risk and reward between capital providers and users. ${ }^{54}$

At its simplest level conventional financing takes the form of equity or debt. ${ }^{55}$ Equity financing means giving an ownership interest or shares of common stock to an investor with its attendant risk of investment loss in exchange for the opportunity to participate in gains or profits. Debt financing involves borrowing money and not giving up ownership or an interest in the asset or going concern. The creditor or lender has its

$$
{ }^{52} \text { Ibid. }
$$

${ }^{53}$ Archer, Simon and Karim, Rifaat Abdel. 2002. Islamic Finance: Growth and Innovation. London: Euromoney Books.

Azhar, Rauf. November 15, 2009. Economies of an Islamic Economy, Themes in Islamic Studies, Vol. 6, https://doi.org/10.1163/ej.9789004179370.i-470.

${ }^{54}$ El Qorchi, Mohammed. 2005. "Islamic Finance Gears Up." Finance and Development 42(4), 46; El-Gamal, Mahmoud A. 2006. Islamic Finance: Law, Economics and Practice. Cambridge: Cambridge University Press.

${ }^{55}$ Hanif, Muhammad. 2014. "Differences and Similarities in Islamic and Conventional Banking." International Journal of Business and Social Sciences 2(2), 26. 
loan secured through a mortgage or through personal property security regimes. ${ }^{56}$ In some cases it may even be an unsecured loan. The debtor must, of course, invariably pay a fixed return in the form of interest, which a majority of Islamic scholars translate as riba. Islamic-compliant products attempt to shift this paradigm toward joint-venture and limited partnership structures whereby the profit and loss are shared in agreedupon proportions. To comply with the various rules and prohibitions, numerous investment vehicles and contracts have been developed over the years that have been approved by Islamic jurists (although not all instruments and structures and their permutations or iterations are accepted by all scholars). These include, among others, murabahah, ijarah, mudharabah, musharaka, istisna, takaful, and sukuk. ${ }^{57}$

\section{Murabahah ("Rent to Own”)}

The most commonly used transaction is the murabahah, where a commodity or asset is purchased by the financier for the buyer, who then pays the cost plus a fixed "profit" or mark-up over a period of time. ${ }^{58}$ The purchase and sale price, costs, and the profit margins must be clearly agreed to between the parties at the outset. The asset must remain under the ownership of the financing institution until the agreed marked-up price for the asset is fully paid by the customer. ${ }^{59}$ In some ways, it is similar to a rent-to-own type of arrangement. Most Islamic finance companies offering "Shari'ah-compliant" mortgages use a variation of this model, or at least claim to do so. One of the major problems from an Islamic perspective is that, contrary to the theory, in practice the Islamic finance company does not keep title for liability, practicality, or out of legal/regulatory

${ }^{56}$ Security is registered in a land registry office when real property is involved or through a personal property security registration regime on a priority and attachment basis.

${ }^{57}$ Hussain, Mumtaz, Shahmoradi, Asghar, and Turk, Rima. 2015. "An Overview of Islamic Finance," IMF Working Paper, https://www.imf.org/external/pubs/ft/wp/ 2015/wpl5120.pdf; El-Gamal, Mahmoud A. 2006. Islamic Finance: Law, Economics and Practice. Cambridge Cambridge: University Press.

${ }^{58}$ Qazi, Irfan. 2008. "Murabaha Financing vs. Lending on Interest.” Retrieved from https://ssrn.com/abstract=1803651 or http://dx.doi.org/10.2139/ssrn.1803651; Rammal, Hussain Gulzar. 2004. "Financing Through Musharaka: Principles and Application." Business Quest. Retrieved from https://ssrn.com/abstract $=1442430$.

${ }^{59}$ Ibid., Qazi, Irfan. 
considerations. When one factors in the use of security in the form of a mortgage versus keeping title, amortization schedules that do not match the term, terms that are less than the length required to pay off the full value, rates pegged to the market interest rate, etc., it becomes easy to imagine how the lines between interest/profit and conventional/Islamic finance get blurred.

A traditional murabahah structure is also employed quite often in the trade finance context. ${ }^{60}$ For instance, a customer needs to buy goods but cannot afford funds up front, but there is a financier prepared to facilitate the transaction by advancing the funds. The financier buys the goods, paying full price on delivery, and upon receipt of the goods immediately sells it at a mark-up (a single payment at a later date or pre-agreed schedule) within an agreed-upon time. Depending on the reference points used, profit calculation formula, and amortization schedule used, this murabahab could easily mirror a conventionally financed transaction with Arabic terminology substitutions.

It works slightly differently in the commodity contexts. In the commodity context, upon receipt of the murababah financed goods, the customer will immediately sell the goods back into the market with a mark-up immediately or in a deferred transaction. ${ }^{61}$ Unlike a traditional murabahah (where the financing is to facilitate acquisition of a property or equipment that the customer actually wants), a commodity murabahah structure can be used to facilitate the flow of funds to an entity, even where the entity does not want the underlying commodity (raising the concern about money making money in the Islamic context). The only additional requirement is that the commodity is not haram.

Murabahah finance appears to be the closest to a conventional loan and the most straight-forward to effect. For this reason, as well as the way that murabahab is used today by Islamic finance companies, the murababah structure has attracted the most criticism from Islamic scholars and

${ }^{60}$ Murabahah Trade Financing. Maldives Islamic Bank, http://www.mib.com.mv/ pages/view/murabahah-trade-financing; El-Gamal, Mahmoud A. 2006. Islamic Finance: Law, Economics and Practice. Cambridge: Cambridge University Press.

${ }^{61}$ For an explanation of murabaha, see https://nscpolteksby.ac.id/ebook/files/Ebook/ Accounting/Ethica\%20Handbook\%20of\%20Islamic\%20Finance/25.\%20MURABAHA.pdf; El-Gamal, Mahmoud A. 2006. Islamic Finance: Law, Economics and Practice. Cambridge: Cambridge University Press. 
finance experts for violating the spirit of Shari'ah principles while blindly adhering to form.

\section{Ijarah ("Lease Finance")}

Another commonly used transaction is the ijarah, where the financier buys an asset from a party to lease to another party or from the customer to then lease it back to the customer for a fixed period, after which the lessee commits to repurchase the asset. ${ }^{62}$ The financial institution is entitled to a predetermined rental fee. ${ }^{63}$ In essence, the ijarah structure is the equivalent of a traditional finance lease. In the Islamic context, it is arguably the second most common instrument, most often used for real property or asset financing. The asset is essentially sold to the customer at the end of the ijarah contract (or in the event of default) for a pre-agreed buyout price plus any accrued and unpaid rent. In some situations, the underlying asset may be split up (actually or theoretically on a percentage basis) to allow for a sculpted reduction in the purchase price payable or to allow for partial (voluntary or involuntary) payments of the purchase price during the term of the ijarah contract (to mirror amortization or early repayment under a conventional term loan). Again, Islamic jurists have differences of opinion as to what is permitted and what is not in the context of ijarah.

\section{Mudharabah ("Profit/Loss Sharing”)}

Mudharabah refers to a profit-sharing contractual agreement between a financial institution or investor and an entrepreneur. ${ }^{64}$ This can be

${ }^{62}$ Hussain, Mumtaz, Shahmoradi, Asghar, and Turk, Rima. 2015. "An Overview of Islamic Finance," IMF Working Paper, https://www.imf.org/external/pubs/ft/wp/ 2015/wp15120.pdf; El-Gamal, Mahmoud A. 2006. Islamic Finance: Law, Economics and Practice. Cambridge: Cambridge University Press.

${ }^{63}$ Zaher, Tarek S. and Hassan, M. Kabir. 2001. "A Comparative Literature Survey of Islamic Finance and Banking." Financial Markets, Institutions \& Instruments 10(4), 155-199.

${ }^{64}$ Hussain, Mumtaz, Shahmoradi, Asghar, and Turk, Rima. 2015. "An Overview of Islamic Finance," IMF Working Paper, https://www.imf.org/external/pubs/ft/wp/ 2015/wp15120.pdf; El-Gamal, Mahmoud A. 2006. Islamic Finance: Law, Economics and Practice. Cambridge: Cambridge University Press; Shaikh, Salman Ahmed. 2011. "A Critical Analysis of Mudarabah \& A New Approach to Equity Financing in Islamic 
viewed as "venture capital." At its core, it is a contract that provides for profit sharing between the investor and the entrepreneur who contributes skill, time, or goodwill. While the financial institution provides the necessary capital (rabb-ul-mal), the entrepreneur (mudarib) provides the operational capabilities. In the event of a loss, the financial institution loses its capital and the entrepreneur loses his or her invested labor and other intangible contributions. ${ }^{65}$ The salvage value belongs to the entrepreneur based on the Shari'ah dictate that the rabb-ul-mal should absorb all losses. Under this arrangement, money contributed by the capital provider (rabb-ul-mal) is invested by the entrepreneur (mudarib) in the business and is used to acquire "assets" (interpreted very broadly in this context so that no tangible asset is required) with the goal of profit generation. ${ }^{66}$ The mudharabah agreement typically stipulates that the mudharabah will generate profits periodically for set periods at a preagreed scheduled rate. All profit generated by the business is distributed between the rabb-ul-mal and the mudarib as previously agreed. Similar to the ijarah model, the agreements provide mechanisms for repayment of the original investment amount and for termination (on expiry, or earlier default).

\section{Musharaka ("Partnership with Profit/Loss Sharing")}

Musharaka is literally translated as "sharing." 67 Musharaka is a partnership in which both the customer and financial institution provide capital

Finance." Journal of Islamic Banking of Finance. Retrieved from https://ssrn.com/ abstract $=1930173$.

${ }^{65}$ Shaikh, Salman Ahmed. 2011. "A Critical Analysis of Mudarabah \& A New Approach to Equity Financing in Islamic Finance." Journal of Islamic Banking \& Finance. Retrieved from https://ssrn.com/abstract=1930173; Bacha, Obiyathulla I. 1997. "Adapting Mudarabah Financing to Contemporary Realities: A Proposed Financing Structure." INCEIF the Global University in Islamic Finance, https://mpra.ub.uni-muenchen.de/ 12732/1/MPRA_paper_12732.pdf.

66 Ibid.

${ }^{67}$ Musharakah Investopedia, https://www.investopedia.com/terms/m/musharakah.asp; Hussain, Mumtaz, Shahmoradi, Asghar, and Turk, Rima. 2015. "An Overview of Islamic Finance," IMF Working Paper, https://www.imf.org/external/pubs/ft/wp/ 2015/wp15120.pdf; El-Gamal, Mahmoud A. 2006. Islamic Finance: Law, Economics and Practice. Cambridge: Cambridge University Press; Rammal, Hussain Gulzar. 2004. Financing Through Musharaka: Principles and Application. Business Quest. Retrieved from https://ssrn.com/abstract=1442430. 
and share profits and losses based on a contract between the two parties concluded before the transaction is finalized. It is among the more common methods utilized to engage in project finance, real-estate purchases, letters of credit, and other investment projects. ${ }^{68}$ Another form of musharakah that has surfaced relatively recently is the "diminishing musharakah." According to this concept, an investor and customer or partner will participate either in the joint ownership of property or equipment, or in a joint commercial enterprise. Under the diminishing musharakah model, the share or interest of the investor will be paid off periodically along with the agreed profit. The investor's share or interest will therefore decrease and will eventually be paid off fully leaving the customer or partner the sole owner of the property, or the commercial enterprise, as the case may be.

A contract of mudharabah normally presumes that the mudarib (entrepreneur) has not invested capital to the mudharabah. The mudarib is responsible for the management only, while all the investment comes from rabb-ul-mal. Conversely, the musharaka is the preferred vehicle when the mudarib also wishes to invest capital into the business of mudharabah. In such cases, musharakah and mudharabah are combined together. This is typically how it is done in the real estate market.

\section{Istisna (“Agreement for Future Delivery")}

Istisna involves a funding party agreeing to produce, procure, manufacture, or construct and deliver a commodity or an asset at a predetermined future time at an agreed price to another party. ${ }^{69}$ The asset or commodity is sold for an amount equivalent to the aggregate of all phased payments made plus a profit margin. This vehicle is often used in project or real estate development financing to facilitate the advance of monies during the construction phase. In such circumstances, to facilitate a long-term

${ }^{68}$ Qadri, Shahzad. 2007. "Islamic Banking-An Introduction." Business Law Today $17(6), 59$.

Rammal, Hussain Gulzar. 2004. "Financing Through Musharaka: Principles and Application." Business Quest. Retrieved from https://ssrn.com/abstract=1442430.

${ }^{69}$ Hussain, Mumtaz, Shahmoradi, Asghar, and Turk, Rima. 2015. "An Overview of Islamic Finance," IMF Working Paper, https://www.imf.org/external/pubs/ft/wp/ 2015/wp15120.pdf; El-Gamal, Mahmoud A. 2006. Islamic Finance: Law, Economics and Practice. Cambridge: Cambridge University Press. 
financing arrangement, it is very often paired with an ijarah. On completion of the underlying asset, the istisna will be replaced by an ijarah over the completed asset.

\section{Takaful ("Mutual Benefit Society")}

Takaful, which is often translated as Islamic insurance, is essentially a mutual benefit society or co-operative system that aims to serve as a safety net for members in case of loss. ${ }^{70}$ It serves as an alternative to conventional insurance products that are seen as violating Islamic restrictions. Takaful policyholders make contributions to a mutual investment pool and agree to guarantee each other. ${ }^{71}$ Contributions are based on the type of coverage policyholders require and their personal circumstances. Similar to conventional insurance, a takaful contract specifies the nature of the risk and time period of coverage. ${ }^{72}$

\section{Sukuk (“Investment Certificate")}

Sukuk, commonly referred to as Islamic bonds, is more accurately translated as "Islamic investment certificates." understood as a contractual debt obligation, and the bond issuer is obligated to pay the bondholder both the principal as well as the interest at agreed-upon intervals. ${ }^{74}$ The primary difference between sukuk and a traditional bond is that sukuk is technically not debt and does not pay the security holder interest. ${ }^{75}$ Instead, sukuk holders become shareholders,

${ }^{70}$ For an explanation of takaful, see https://www.lexisnexis.com/uk/lexispsl/ bankingandfinance/document/391289/5BNP-XNT1-F185-X3CF-00000-00/Takaful_ overview.

71 Ibid.

72 Ibid.

${ }^{73}$ Thomas, Abdulkader, Cox, Stella, and Kraty, Bryan. 2005. Structuring Islamic Finance Transactions. Linnius; Box, Tamara and Asaria, Mohammed. 2005. "Islamic Finance Market Turns to Securitization." International Financial Law Review 24, 21.

${ }^{74}$ Koch, Michael. "Sukuk vs Conventional Bonds: A Study into the Performance of Islamic Bonds," https://pdfs.semanticscholar.org/e830/ 9e00e7de945a3e6lae4447208ee7a02e3b0f.pdf.

75 Abdel-Khaleq, Ayman and Richardson, Christopher. 2007. "New Horizons for Islamic Securities: Emerging Trends in Sukuk Offerings." Chicago Journal of International Law 7(2), 409-413. 
Table 7.1 Summary of key Islamic finance instruments

\begin{tabular}{ll}
\hline Arabic name of the financial instrument & Summary \\
\hline Murabahah & $\begin{array}{l}\text { Cost plus mark up/rent to own type of } \\
\text { arrangement }\end{array}$ \\
Ijarah & $\begin{array}{l}\text { Financial lease } \\
\text { Profit/loss sharing contract }\end{array}$ \\
Mudharabah & $\begin{array}{l}\text { Partnership with profit/loss sharing } \\
\text { Agreement to deliver a product or service } \\
\text { Istisna }\end{array}$ \\
at a time in future at an agreed price \\
Mukaful & $\begin{array}{l}\text { Mutual benefit society to pool and share } \\
\text { risks } \\
\text { Buknd like investment certificate that } \\
\text { converts into equity }\end{array}$ \\
\hline
\end{tabular}

holding the assets that are then leased back to the original company for an asset-related return over a predetermined period of time based upon the profit from the underlying assets. ${ }^{76}$

Each of these products/structures have numerous variations and iterations. There are many other products and instruments but the foregoing provides a good overview of the field and should give one a sense of how Islamic finance works. Table 7.1 provides a summary. The overview in this Part should also help shed some light on the potential for differences of opinion on the Shariah-compliance of the different products and vehicles. It also reveals the potential for confusion, misunderstanding, and even obfuscation and deception by unscrupulous actors who may wish to exploit religious sentiments. The next Part touches upon challenges, especially consumer protection concerns, that evolve from the status quo.

\section{Practical Issues in Implementing Islamic Finance}

While, at least theoretically, Islamic finance has much to offer with regard to economic and social justice, financial management, and ethics, the Islamic finance industry of today faces significant challenges, especially outside the Muslim world. Some of these issues are germane in Muslim states, too, but they are more pronounced or unique to jurisdictions that do not have an overarching Islamic judicial or regulatory body.

${ }^{76}$ Ibid. at 424 . 
These challenges include the following: (1) lack of knowledge and sophistication on the part of Muslim consumers and the non-existence of uniform standards; (2) shortage of experts with an understanding of Islamic rules, finance, law, and their interactions; (3) lack of sophistication, professionalism, and the resulting lack of credibility; (4) legal impediments, regulatory confusion, and lack of oversight; and (5) politics and public opinion. A few of these issues are highlighted below to provide an overview.

\section{LACK of KNowledge on the Part of Muslim Consumers and THE Non-EXISTENCE OF UNIFORM STANDARDS}

Far too many consumers lack basic knowledge about finance and financial risk and may make unwise financial decisions. They may also be easily duped by fraudsters and high-powered salespeople. This is the main reason that governments often have extensive rules and regulations when it comes to investments and financial schemes. This is true for all money matters, but as the foregoing discussion on Islamic finance illustrates, the situation can be even more complex when there is a marriage between finance and faith. ${ }^{77}$

Mahmoud Amin El-Gamal, a leading critic of the Islamic finance industry, argues that the industry is selling overpriced products to the religiously naive. He claims that sophisticated investors and the ultraorthodox religious players will see through what is being done in the name of Islamic finance, but he notes, "So you're left with the gullible who don't really understand the structure." 78 This is all the more dangerous when the faith is blind as is the case too many times when religious followers put their trust in pious and charismatic individuals or groups who use religion to advance their agendas including financial ones. ${ }^{79}$

77 "A Study of Retail Islamic Banking: The Relationship between Customer Knowledge and Service Quality," Khairul Firdaus Adrutdin\#1, Azlan Ali*2, Jimisiah Jaafar\#3, Sallaudin Hassan\#4 Nur Syafiqah A. Rahim\#5 http://ojs.excelingtech.co.uk/index.php/IJSCM/ article/view/1194.

${ }^{78}$ Marais, Richard. 2007. "Don't Call It Interest." Forbes, https://www.forbes.com/ forbes/2007/0723/122.html\#242132b74354.

${ }^{79}$ Here is an example of an article in a Muslim publication which essentially regurgitates what ijara, an Islamic finance company, says they 
Professor El-Gamal may be giving the ultraorthodox Muslims too much credit, because from my experience working with Islamic finance products, most Muslims, even the ultraorthodox, have a very limited or cursory understanding of Islamic finance in practice. The key questions are: (1) how do we get religious consumers to be more inquisitive, and (2) how do we get them to do more due diligence: This is particularly important given that consumer protection legislation in this context is virtually non-existent or deficient. The problem is heightened in nonMuslim jurisdictions because of a lack of awareness as to what is being done in the name of Islamic finance and the reluctance on the part of governments to intervene in a community's internal religious questions. Muslim jurisdictions are not immune either. Many of them are relatively unsophisticated in terms of consumer protection and lack the ability to effectively dictate what is or is not Shariah-compliant, because that is the realm of the religious establishment (many of whom are independent and/or unregulated by the state) for the most part.

Those who actually study Islamic finance will quickly realize that one of the central and highly debatable questions in Islamic finance is whether Islamic financial institutions actually avoid interest-based instruments, or simply reframe or relabel them in order to "comply" with Islamic law. 80 In Partnership, Equity-Financing and Islamic Finance: Whither Profit-Loss Sharing? Mohammad Omar Farooq argues that in order to attempt to avoid interest, Islamic finance has developed "an impressive array" of transactional modes that claim to be based on profit-loss-sharing (PLS). ${ }^{81}$ However, while the Islamic finance literature "continues to emphasize PLS as the main modes, in practice Islamic financial institutions (IFIs)

are doing: https://muslimlink.ca/islamic-finance/ijara-cdc-islamic-halal-mortgage-homefinancing-canada-how-does-it-work. At the bottom it indicates that it is a paid advertisement but most readers will not even get to that part. In practice, the structure through ijara is not different from a conventional loan with the caveats as noted below in the discussion in 2 below on UM Financial.

${ }^{80}$ Farooq, Mohammad Omar. 2007. "Stipulation of Excess in Understanding and Misunderstanding Riba: The Al-Jassas Link.” Arab Law Quarterly 21(4), 285-316.

El-Gamal, Mahmoud A. 2003. "Interest' and the Paradox of Contemporary Islamic Law and Finance." Fordham International Law Journal 27(1), Article 6, https://pdfs. semanticscholar.org/8cb7/0cc8baaf9l lad52f932205al722f76e3f049.pdf.

${ }^{81}$ Farooq, Mohammad Omar. 2007. "Partnership, Equity-Financing and Islamic Finance: Whither Profit-Loss Sharing." Review of Islamic Economics 11, 67 at 67-68. 
have deliberately and systematically avoided them." 82 Farooq goes on to argue that partnership modes of business organization, such as PLS, are inherently flawed, and that it is thus economically rational for Islamic financial institutions to use debt-like instruments while claiming compliance with Islamic law under the guise of PLS-like equity-based systems. ${ }^{83}$ Meanwhile, in practice, instead of PLS systems, Islamic finance has turned toward the murabahah, a model that often carries no risk for the Islamic finance institution, despite risk-sharing being one of the key conceptual components of Islamic finance. ${ }^{84}$ The mark-up model of the murabahah leaves all the risk on the buyer, except in the case of death or default, similar to conventional finance. ${ }^{85}$ While "Islamically there is nothing wrong with murabahah," there is also "nothing especially Islamic about it, either ... Banking primarily based on this type of transactions robs IFIs of distinctively Islamic characteristics." 86 Murabahah is ultimately not as Shari'ah-compliant as is generally claimed, and it is criticized by many scholars as well as some Islamic Financial institutions. ${ }^{87}$ This leads to a "basic contradiction." where the PLS models continue to dominate the literature; yet, in practice, IFIs continue to use murabahah and other modes that are functionally non-PLS and similar to conventional financial instruments. ${ }^{88}$ While IFIs "proclaim that the conventional financing based on interest is unjust since there is no fair sharing of profit-loss and risk," they themselves "do not utilize PLS modes substantively in their portfolios." 89 Farooq goes so far as to suggest that IFIs "make up ruses" to "manufacture products and services that are only legally Islamic,"

${ }^{82}$ Ibid. at 68; Dar, Humayon A. and Presley, John R. 2000. "Lack of Profit Loss Sharing in Islamic Banking: Management and Control Imbalances." International Journal of Islamic Financial Services 2(2), 3-18.

${ }^{83}$ Ibid. Warde, Ibrahim. 1999. "The Revitalization of Islamic Profit-and-Loss Sharing." Proceedings of the Third Harvard University Forum on Islamic Finance: Local Challenges, Global Opportunities. Cambridge, MA: Center for Middle Eastern Studies, Harvard University. 199-211, http://ifpprogram.com/login/view_pdf/?file=The\%20Revitalization\% 20of\%20Islamic\%20Profit-and-loss\%20Sharing.pdf\&type=Project_Publication.

${ }^{84}$ Ibid. at 70 .

85 Ibid. at 71 .

${ }^{86}$ Ibid. at 72 .

${ }^{87}$ Ibid. at 73 .

88 Ibid. at 74 .

${ }^{89}$ Ibid. at 85 . 
but have little difference in substance from conventional financial instruments. ${ }^{90}$ Farooq is not the only one or the first to make such claims. ${ }^{91}$

This gap between the theoretical discourse and the practice of IFIs may be due to an exaggeration of the "usefulness" of PLS models. 92 This exaggeration, in turn, may stem from a second fundamental issue within Islamic finance: the definition of riba. Specifically, the notion that riba, which is prohibited in Islam, is broadly equivalent to interest. While the traditional understanding of Muslims is that riba is equivalent to any interest, some scholars, such as Farooq, El-Gamal, Kuran, Rauf, and others argue that it only means "usury would be prohibited" but that "interest in all its forms as it exists in modern economy and finance can't be necessarily categorized as prohibited."93 While the Quran does not explicitly define riba, the common understanding is that the traditional definition is arrived at via six hadiths. In an analysis of these hadiths, Farooq finds that it is a "daunting task" to utilize these hadiths to broaden riba's scope "to contend that all forms of interest ... in a modern economy are prohibited." 94 Should the common understanding of riba be modified to a more narrow understanding of interest, IFIs would have more flexibility in the types of financial instruments they could offer. Moreover, even if one is to accept the traditional view of riba, consumers should be aware that there are differences of opinion on this issue.

The differences in interpretation of riba are not only being advanced by "modernists" or "liberals." Even a group of conservative jurists passed

${ }^{90}$ Ibid. at 86.

91 El-Gamal, Mahmoud A. 2003. "'Interest' and the Paradox of Contemporary Islamic Law and Finance." Fordham International Law Journal 27(1), Article 6, https://pdfs. semanticscholar.org/8cb7/0cc8baaf9llad52f932205al722f76e3f049.pdf; Kuran, Timur. 2004. Islam and Mammon: The Economic Predicaments of Islamism. Princeton: Princeton University Press; Hamoudi, Haider Ala. 2006. "Muhammad's Social Justice or Muslim Cant?: Langdellianism and the Failures of Islamic Finance." Cornell International Law Journal 40(1), Columbia Public Law Research Paper No. 06-116.

92 Dar, Humayon A. and Presley, John R. 2000. "Lack of Profit Loss Sharing in Islamic Banking: Management and Control Imbalances." International Journal of Islamic Financial Services 2(2), 3-18.

${ }^{93}$ Farooq, Mohammad Omar. 2009. "Riba, Interest and six Hadiths: Do We Have a Definition or a Conundrum?” Review of Islamic Economics 13(1), 105, 107.

Azhar, Rauf. November 15, 2009. Economies of an Islamic Economy, Themes in Islamic Studies, Vol. 6, https://doi.org/10.1163/ej.9789004179370.i-470.

${ }^{94}$ Farooq, Mohammad Omar. 2009. "Riba, Interest and six Hadiths: Do We Have a Definition or a Conundrum?" Review of Islamic Economics 13(1), 138. 
a fatwa permitting interest-based transactions as a necessity in the West given the lack of viable alternatives and the importance of acquiring a residence as a foundation for economic empowerment. ${ }^{95}$ They did by inference add a few caveats, including the following: ( 1 ) there must be no viable and practical Islamic alternative available; $(2)$ the house to be purchased must be for the buyer and his household; (3) the buyer must not have another house; (4) the buyer must not have any surplus of assets that can help him buy a house by means other than mortgage, and (5) the buyer must be actively working for or seeking out Sharia'b-compliant options. ${ }^{96}$

Another issue is the lack of uniform standards within a regulatory framework, creating large differences in practices and variations in instruments that all pass as "Shari'ah-compliant." 97 What is and what is not Shari'ah-compliant differs widely depending on the school of jurisprudence and the geographic area-and even within these domains, because each scholar's opinion is considered valid by his or her respective followers. ${ }^{98}$ There is no official clergy or central religious authority (at least in the Sunni context) that can be called upon to give the final word on what is Islamic finance or even Islamic law.

95 European Council for Ifta' and Research and the Conference of the League of Shari'ah Scholars of North America, "Permissibility of Conventional Mortgage Under Necessity." Fourth Ordinary Session (October 27-31, 1999) Resolution 2/4, https://eshaykh. com/halal_haram/permissibility-of-conventional-mortgage-under-necessity/ and http:// www.islamicmortgages.co.uk/index.php?id=259.

${ }^{96}$ Ibid. For a rebuttal, see Salah al-Sawi. June 21, 2001. A Polite Reconsideration of the Fatwa Permitting Interest-Based Mortgages for Buying Homes in Western Societies, translated by Usama Hasan, https://unityl.files.wordpress.com/2009/06/analysis-of-fatwason-mortgages.pdf.

${ }^{97}$ Wafik, Grais and Pellegrini, Matteo. 2006. Corporate Governance and Shariah Compliance in Institutions Offering Islamic Financial Services. World Bank Policy Research Working Paper No. 4054; Stubing, Darren. 2015. "Islamic Finance Held Back by Lack of Supervision, Liquidity." Global Finance, https://www.gfmag.com/magazine/may-2015/ lack-supervision-liquidity-holding-back-islamic-finance.

98 Pock, Alexander. 2007. Strategic Management in Islamic Finance. Berlin: Springer Science \& Business Media; Farook, Sayd Zubair and Farooq, Mohammad Omar. 2013. "Shariah Governance, Expertise and Profession: Educational Challenges in Islamic Finance." ISRA International Journal of Islamic Finance 5(1), 137-160; Box, Tamara and Asaria, Mohammed. 2005. "Islamic Finance Market Turns to Securitization." International Financial Law Review 24, 21. 
Different countries and different sects-and even schools of Islamic thought within those countries and sects-each have their own interpretation of religious as well as financial teachings of Islam. Contrary to popular perception, Islamic law is not monolithic. Rather, it is pluralistic and dynamic and, therefore, allows for flexibility to meet the demands of the changing social and economic circumstances, but it also creates obvious obstacles from a legal/regulatory and practical perspective. In the absence of a supreme authority (e.g., the highest court in jurisdiction for instance) with the power to rule on whether something is ultimately Shari'ah-compliant, the rules may be unpredictable and susceptible to a multitude of interpretations that result in "fatwa shopping." Interestingly, some scholars and critics have highlighted this practice, whereby Islamic finance bodies search out "Islamic" legal opinions to justify or rationalize what they want to do rather than seeking out the most reliable or "authentic" rulings in line with the spirit and letter of Islam. 99 In fact, studies have demonstrated that some Islamic finance professionals search for favorable scholars for quick recognition of products ${ }^{100}$ thereby giving an Islamic identity to products that are de facto conventional in nature. ${ }^{101}$

Education and reflection are critically important but highly unlikely to bear any immediate fruit because of the complexity of the field and the belief among many Muslims that they simply need to have good intentions and should leave the mechanics to "scholars." The fact that unscrupulous actors may take advantage of them is brushed off: "My intentions are good, if they want to dupe me then they will face God on the day of judgement." 102 Although an understandable theological position, this fatalistic view is fertile ground for exploitation.

${ }^{99}$ Oseni, Umar A., Ahmad, Abu Umar Faruq, and Hassan, M. Kabir. 2016. "The Legal Implications of 'Fatwā Shopping' in the Islamic Finance Industry." Arab Law Quarterly 30(2), 102-137.

${ }^{100}$ Hassan, M.K. and Dicle, M.F. 2007. "Basel II and Corporate Governance in Islamic Banks." in S.N. Ali (ed.), Integrating Islamic Finance into the Mainstream: Regulation, Standardization and Transparency. Cambridge, MA: Islamic Finance Project, Harvard Law School, 2007, 31-50.

${ }^{101}$ Khan, F. 2010. How “'Islamic' Is Islamic Banking?” Journal of Economic Behavior \& Organization 76(3), 818.

102 This is a typical conversation with clients when reviewing the obfuscation used by some Islamic finance entities. 


\section{Shortage of Experts with Simultaneous Understanding of Islamic Rules, Finance and Law}

The dearth of competent specialists trained in the field is a widely highlighted global problem in Islamic finance. ${ }^{103}$ Many have argued that there is a lack of human capital with Islamic finance know-how. ${ }^{104}$ I suspect the problem is not a shortage of Islamic scholars with know-how about Islamic finance, because this is not necessarily accurate. ${ }^{105}$ As Zulkifli Hasan notes, there are plenty of scholars with Islamic finance knowledge, but institutions stick with a known group for credibility and business reasons. I would also add that some are relied on because companies get what they want from these Shari'ah scholars who are paid handsomely and some of whom sit on dozens of boards. ${ }^{106}$ Sometimes the problem is exacerbated even when people have Islamic finance training or knowledge, because they do not appreciate or understand the whole picture. This results in approval of documents, instruments, or structures that are no different from conventional finance options, and sometimes it even results in these scholars or specialists being used to market exploitative or egregiously non-Shariah-compliant products and services. Scholars or specialists who lack a more holistic understanding or who fail to appreciate the technical and complex interplay often involved in such documents or transactions are sometimes inadvertently duped by shady businesspeople or occasionally even well-meaning proponents of Islamic finance. ${ }^{107}$

103 Abbas, Mohammed. February 2, 2008. "Shortage of Scholars Troubles Islamic Banking." The New York Times, https://www.nytimes.com/2008/01/22/business / worldbusiness/22iht-bank.4.9412578.html; Barreh, Ismail. "Scholar Shortage Threatens Islamic financing industry." MuslimLink, https://muslimlink.ca/islamic-finance/scholarshortage-threatens-islamic-financing-industry.

104 Ibid.

${ }^{105}$ Hasan, Zulkifli. 2012. "Demystifying the Myth of Shortage of Shari'ah Scholars," https://zulkiflihasan.wordpress.com/2012/03/02/demystifying-the-myth-ofshortage-of-shariah-scholars-2/.

${ }^{106}$ Inevitably when small cliques dominate and monopolize an industry and money is involved, it is only a matter of time before problems start. See Barreh, Ismail. "Scholar Shortage Threatens Islamic Financing Industry." MuslimLink, https://muslimlink.ca/ islamic-finance/scholar-shortage-threatens-islamic-financing-industry.

${ }^{107} \mathrm{Ha}$, Tu Thanh. 2014. "RCMP Charge Missing Toronto Financier with \$4.3Million Mortgage Fraud." The Globe and Mail, https://www.theglobeandmail.com/ news/national/rcmp-charge-missing-toronto-financier-with-43-million-mortgage-fraud/ article16972349/; Seputis, Jasmine. 2018. "2 Men Defrauded Shariah-Compliant 
In the Canadian context, I have witnessed many schemes being approved as Shari'ah-compliant, such as the "musharakah" agreement used by UM Financial mentioned earlier, when financial institutions are doing nothing more than relabeling, playing with terminology, and drafting parallel documents. In such contracts, even though terminology from Islamic finance is widely used, the key thing is that (1) the borrowers may not fully realize that they are effectively paying "interest" on the loan, because it might be labeled otherwise, and (2) there is a range of opinion among Islamic finance scholars about what products/services are consistent with Islamic principles.

With such contracts, an Islamic scholar who only understood the rules of theoretical Islamic finance would not be able to understand these transactions. The scholar must understand the theory of Islamic finance, the practical details, and the conventional loan procedures, as well as the legal and real estate practice and procedures. Such people are few and far between. ${ }^{108}$

\section{LACK OF PROFESSIONALISM AND the Resulting Lack of CRedibility}

Though there are some studies focusing on customer satisfaction with Islamic finance companies in the Muslim world, there appear to be no such studies in the context of Islamic finance companies in the West. Anecdotally, the customer service landscape in the western Islamic finance market is far from glowing. As small-time operators or community-based groups, customer service is usually not their forte. The disgruntled client, whose story I shared at the start of this chapter, only went to the Law Society because he thought I was part of UM. Moreover, he had been

Mortgage-Holders of Millions of Dollars, Crown Tells Trial." CBC News, https://www. cbc.ca/news/canada/toronto/2-men-defrauded-shariah-compliant-mortgage-holdersof-millions-of-dollars-crown-tells-trial-1.4867083; Sweeney, Annie. March 28, 2011. "Guilty Plea in Fraud Scheme That Targeted Muslim community." The Chicago Tribune, https://www.chicagotribune.com/news/ct-xpm-2011-03-28-ct-met-muslim-fraud-guilty20110328 -story.html.

${ }^{108}$ I have carried out what I call the "coke" v. "pepsi" equivalent test ("conventional mortgage" v. "Islamic Finance" test) on some Islamic scholars who have given opinions on Islamic finance products, and they were not able to differentiate between the two. In fact, in at least two cases, the scholars chose the "conventional" as more "fair," "just," "reasonable," "more affordable," and "less exploitative." 
unable to get a satisfactory response from UM on his questions or complaints even after months of trying. He found it difficult to reach UM and when he did, they were unresponsive. UM is not alone in lacking professionalism and sophistication. As small, independent, private, and non-mainstream, Islamic finance entities cannot be expected to meet the service levels people have grown to expect from conventional financial institutions. Much of this has to do with limitations in terms of financial resources, human resources, and, to some extent, even cultural factors. This of course creates a vicious circle that results in even poorer service over time and lowered expectations.

Given that the competitive advantage of Islamic banking lies in the fact that the products and services offered are indeed Shariab-compliant, some of the practices described earlier in this chapter diminish public faith in Islamic finance companies. While Islamic financial institutions usually have internal boards to verify that their products comply with Islamic principles, this approach "gave rise to conflicting rulings and products of Islamic banking that confused clients and investors," notes a 2017 statement by the Accounting and Auditing Organisation for Islamic Financial Institutions (AAOIFI). "If the confusion persists, the credibility of Islamic banking and finance as a whole may be jeopardized."109 Consumer confidence is also impacted significantly when there are damaging reports, such as UM going into receivership or its principals being charged with criminal fraud.

The situation will not improve until Islamic financial institutions take concrete steps to implement standards. The Islamic banking world has increased its efforts to standardize regulation and supervision. The Islamic Development Bank is playing a key role in developing internationally acceptable standards and procedures for strengthening the sector's architecture in different countries. Moreover, international organizations, such as the AAOIFI, the Islamic Finance Service Board (IFSB), the International Islamic Financial Market, the Liquidity Management Center, and the International Islamic Rating Agency, are working to set Shari'ahcompliant standards and harmonize them across countries. ${ }^{110}$ However, despite the efforts of these international organizations to place the Islamic

${ }^{109}$ Domat, Chloe. 2018. "Towards Standards in Islamic Finance." Global Finance, https://www.gfmag.com/magazine/march-2018/toward-global-islamic-finance-standard.

${ }^{110}$ El Qorchi, Mohammed. 2005. "Islamic Finance Gears Up." Finance and Development 42(4), 46. 
finance industry on a sound footing, "there are no generally acceptable guidelines or standards on accounting, auditing, legal, governance, and Shari'ah issues as yet." 111 Moreover, the problem is even worse in nonMuslim jurisdictions for obvious reasons.

Unsurprisingly the fragmented regulatory structure of Islamic finance has attracted criticism. Academics and practitioners alike have argued that the lack of standardization of Shari'ah rules creates problems of consistency, predictability, and fairness. Several commentators have argued that such a fragmented regulatory structure hinders the success and advancement of Islamic finance, and it also reinforces consumer protection concerns as well as consumer confidence. ${ }^{112}$

In addition to issues of expertise, the absence of holistic and interdisciplinary knowledge, the lack of standardization as well as the potential conflict of certifiers serving as regulators, and of course "fatwa shopping" are problematic for the practice of Islamic finance. This is all the more dangerous given that some of these same scholars are also serving as auditors, standard setters, legislators, and regulators.

\section{LEGAL IMPEDIMENTS, REgULATORY CONFUSION AND LACK OF OVERSIGHT}

There are currently two predominant types of regulatory regimes governing Shari'ah-compliant institutions in Muslim countries. One approach

${ }^{111}$ Oseni, Umar A., Ahmad, Abu Umar Faruq, and Hassan, M. Kabir. 2016. "The Legal Implications of 'Fatwā Shopping' in the Islamic Finance Industry." Arab Law Quarterly 30(2) 107-137 at 108 .

${ }^{112}$ See Balz, Kilian, 2007. "Islamic Finance for European Muslims: The Diversity Management of Shari'ah-Compliant Transactions." Chicago Journal of International Law 7(2), 551 .

Intervention by a centralized regulator is essential in a competitive environment to induce Islamic banks to formulate Shariah-compliant financial products. The regulator fixes a structural threshold below which any financial product like Murabaha becomes non-Shariah-compliant. The actual structure of the financial product developed by an Islamic bank is unobserved by the regulator. It only becomes known in the event of an audit conducted by the regulator (the article below by Azmat et al....).

Azmat, Saad, Azad, A.S.M. Sohel, Ghaffar, Hamza, and Bhatti, Ishaq. 2015. "Why Interest Free Islamic Banking Is Not Free from Interest?” https://www.deakin.edu.au/_ _data/assets/pdf_file/0003/392295/islamic-banking-not-free-from-interest-Azmat-AzadGhaffar-and-Bhatti.pdf; Wilson, Rodney. 2004. Capital Flight Through Islamic Managed Funds. Edinburgh: Edinburgh University Press. 
places Islamic institutions under the central bank, but in a regime entirely different from that of the conventional banks. ${ }^{113}$ A second practice recognizes the uniqueness of the Islamic institutions but places them under the same supervision and regulatory regime that governs conventional banks, with slight modifications and special guidelines. ${ }^{114}$ In Canada and the United States, similar to most non-Muslim countries, the industry is governed by a regulatory and supervisory framework developed for conventional finance with no consideration for the uniqueness of Islamic financial institutions. ${ }^{115}$ Therefore, the regulatory regime does not take into account the special nature of Islamic finance, which creates several compliance issues for Islamic financial institutions. ${ }^{116}$

One of the biggest challenges to the development of Islamic finance in Canada and the United States is the difficulty for new institutions getting through the application process to receive a banking license. ${ }^{117}$ Even if an Islamic bank was to get licensed, the restrictions on real estate ownership would obviously be an issue for Islamic-financial institutions, especially if the Islamic finance company wishes to structure "pure" Islamic models. ${ }^{118}$ According to the majority opinion, the Islamic institution must hold legal title until the process is complete. Banking laws may also restrict non-real estate investments, limiting them to fixed-income and interestbearing securities, which are deemed prohibited by most proponents of Islamic finance.

113 (Example, Yemen and Malayisa). El Qorchi, Mohammed. 2005. "Islamic Finance Gears Up." Finance and Development 42(4), 46.

114 (Example, Bahrain and Qatar). Ibid.

115 Islamic Finance: Opportunities, Challenges, and Policy Options, International Monetary Fund.

${ }^{116}$ Canada Islamic Finance Outlook 2016. Toronto Financial Service Alliance, IFSB Working Paper on Financial Consumer Protection In Islamic Finance.

Nienhaus, Volker. 2015. "IFSB Working Paper on Financial Consumer Protection in Islamic Finance. IFSB Working Paper Series.” Islamic Financial Services Board, https:// www.ifsb.org/docs/WP-03-Consumer\%20Protection(final).pdf.

117 http://dtpr.lib.athabascau.ca/action/download.php?filename=mba-11/open/ edwardlauraProject.pdf.

118 In order to structure a house purchase transaction, for instance, the title will have to remain in the name of the Islamic finance company (either solely or jointly) until the transaction is completed. 
Taxes pose another challenge. ${ }^{119}$ Sharia-compliant products generally do not fit within the definitions that currently govern the conventional financial products, despite their similar economic features. Both tax authorities and taxpayers lack knowledge of the specific features of Islamic products. Considering the technical, interpretive, and policyrelated issues, obtaining rulings from the relevant authorities can be quite lengthy and costly. ${ }^{120}$ One glaring tax issue in the context of real property is land transfer. ${ }^{121}$ Institutions that purchase a home and then resell it to the final purchaser may face, in addition to other issues, double or even triple transfer tax costs depending on the transaction and the jurisdiction. Some jurisdictions may have worked around it, but it remains a problem in other jurisdictions. ${ }^{122}$ For instance, in Ontario where the Islamic Cooperative Housing Corporation and Ansar Co-operative Housing Corporation (hereinafter collectively the Co-op) purchase homes for people and keep the title until the Co-op's contribution is paid off, the Ministry of Finance initially did not concern itself with collecting taxes on subsequent transfers. After years of not making it an issue, the Ministry then started reassessing homeowners thousands of dollars in taxes. They took the position that land transfer taxes were payable when the house was initially purchased and again when title is transferred to the actual homeowner. Following meetings with Ministry officials where they were briefed on the structure of the home purchase model, the Ministry tentatively suspended this practice, but there is still no definitive ruling on

119 Canada Islamic Finance Outlook 2016. Toronto Financial Service Alliance.

${ }^{120}$ For details, see Islamic Finance Working Group. 2010. Toronto Financial Service Alliance. Retrieved from http://www.tfsa.ca/resources/pdf/TFSA_IFWG_Prelim_ Report_May14_2010_final_2.pdf.

${ }^{121}$ Land Transfer Tax or Stand Duty Land Tax or Real Estate Transfer Tax are taxes payable on transfers of real properties. There are some exemptions. See, for example, https://www.fin.gov.on.ca/en/tax/ltt/; https://www.gov.uk/stamp-dutyland-tax; https://www.nar.realtor/smart_growth.nsf/docfiles/transfertaxrates(8-05).pdf/ \$file/transfertaxrates(8-05).pdf.

122 Islamic finance/alternative finance arrangements and tax-overview, https://www. lexisnexis.com/uk/lexispsl/tax/document/393773/5BR0-C761-F18C-V2DB-0000000/Islamic_finance_alternative_finance_arrangements_and_tax_overview. 
this despite waiting more than ten years. ${ }^{123}$ This obviously creates uncertainty for the thousands of homeowners who can be reassessed at any point within a certain limitation period.

Another potential issue that may arise is the loss of rebates or credits on property and other tax implications. ${ }^{124}$ The wide variety of the Islamic financial products may alone create the need for significant resources to approach the tax authorities. The interplay and interaction between federal and state/provincial laws, regulations, and policies may raise even more complexities for Islamic finance companies. ${ }^{125}$

Lastly, as touched upon earlier in this chapter, the non-existence of oversight or regulatory bodies in the Islamic context adds to the complexity. At least in Muslim countries some steps are being taken to address this issue. The Bahrain-based AAOIFI is working toward establishing worldwide norms and standards for Islamic finance and banking practices. The AAOIFI, with hundreds of member institutions across forty-five countries, has adopted guidelines to centralize these boards and introduce new standards. Its standards are already widely used within the Islamic finance industry, and are compulsory in some countries. ${ }^{126}$ The fact remains that there are no such standards or regulatory bodies that can oversee them in non-Muslim jurisdictions. This makes it difficult to engage with mainstream authorities in working around regulations, laws, policies, etc.

${ }^{123}$ I met with Ministry of Finance officials on behalf of the Islamic Co-operative Housing Corporation/Ansar Co-operative Housing Corporation.

${ }^{124}$ Some jurisdictions provide property tax relief for residential properties, and some jurisdictions provide relief or rebates from other types of taxes, both of which may not be smoothly accessed when transactions are structured in accordance with Islamic finance rules. I have seen issues with tax authorities that question why a corporation is applying for tax relief for a residential home or how a corporation can claim to reside in a residential property, etc. These issues come about because ownership rests with the institution and other structural factors.

125 See, for example, http://www.woodllp.com/Publications/Articles/pdf/Taxation_ of_Islamic_Finance_Part_l.pdf; https://www.mohammedamin.com/Islamic_finance/ Euromoney-chapter-tax-treatment-of-Islamic-finance.html.

${ }^{126}$ Domat, Chloe. 2018. "Towards Standards in Islamic Finance." Global Finance, https://www.gfmag.com/magazine/march-2018/toward-global-islamic-finance-standard. 


\section{Politics and Public Opinion}

A more recent obstacle, which became exceedingly pronounced in the wake of the tragic events of $9 / 11$, is the false association that Islamic finance is necessarily connected with terrorism, extremism, and even money laundering. ${ }^{127}$ Some anti-Muslim activists have taken it upon themselves to raise the alarm about Islamic finance being a back door to introduce Shari'ah into Western lands. ${ }^{128}$ They are playing on the fear of Shari'ah as it exists in the minds of far too many in this day and age. ${ }^{129}$ This is no exaggeration. Anti-Muslim activists are campaigning and lobbying governments to oppose any accommodation in the Islamic finance context. During my meetings with the Ministry officials on the issue of double land transfer tax on a behalf of my clients, the extent of the lobbying became clear to me. In fact, for more than twenty years the Ministry had no issue with how the transactions were structured, and they did not expect land transfer tax a second time when a property was transferred from the Islamic finance company to the homeowner. The Minister had accepted the following:

1. that the property was initially purchased on behalf of the homeowner;

2. that land transfer tax was paid when the property was acquired from the seller;

3. that the Islamic finance institution was simply holding title as security for the amount it had advanced toward the purchase; and

4. that the structure of the transaction was not to evade taxes but to comply with religious requirements.

The Ministry all of sudden changed its view and started assessing land transfer taxes on all transfers to owners. During the meeting it became

127 https://zulkiflihasan.wordpress.com/2009/12/30/another-sign-of-islamophobia/; https://www.aa.com.tr/en/turkey/islamophobia-prevents-islamic-finance-expansionmalaysian-scholar/219396.

128 https://www.theglobeandmail.com/news/national/banks-are-helping-sharia-makea-back-door-entrance/article1051161/.

129 https://www.nydailynews.com/opinion/silly-american-fear-sharia-law-article-1. 3229045; https://www.thestar.com/opinion/commentary/2017/02/20/factors-toconsider-about-sharia-law-and-ml 03.html. 
clear that it had been lobbied by "people from the community" who feared that allowing Islamic finance would legitimize Shariah and open the doors to all that it supposedly means. This has been a theme advanced by Islamophobes, including some self-proclaimed secular Muslims. I was even asked a hypothetical by one of the attendees: would Muslims who used conventional banks be labeled as apostates if Islamic institutions were available. My answer, of course, was that both systems coexist in Muslim countries and I have yet to hear of anyone being branded an apostate for choosing conventional banking. Islamophobia is alive and well in the Islamic finance context as well.

Contrary to some fear mongering, Islamic finance is not the lead chariot in "Islamization" and is not especially susceptible to money laundering or terrorist financing. ${ }^{130}$ Yes, it can be abused, just as conventional financing can. For the vast majority it is simply an exercise in attempting to integrate their faith into their financial dealings. Though theory and practice diverge in the attempt to implement faith, this should not detract from the idealism of those who seek to abide by it. It certainly should not be seen as part of a conspiracy to spread Shari'ah or fund terrorism.

\section{CONCLUSION}

Islamic finance, in theory, has much to offer to global finance, but its current practice falls far short of Islamic economic and financial ideals. As many scholars and practitioners have pointed out, Islamic finance as it exists in practice today for the most part is a financial system: "characterized by an incoherent web of rules, convenient and specific blindness respecting those rules in particular contexts, and deceptive and obfuscatory measures intended to lend the entire affair a patina of legitimacy as Islamic. Social justice and fairness are not significant components of the system."131 This unfortunate reality should not cloud the need for,

${ }^{130}$ Terrell, Ron. (2007). "Islamic Banking: Financing Terrorism or Meeting Economic Demand?" (thesis). Naval PostGraduate College, https://apps.dtic.mil/dtic/tr/ fulltext/u2/a475770.pdf; See also https://www.acamstoday.org/islamic-finance-moneylaundering-and-terrorist-financing/.

${ }^{131}$ Hamoudi, Haider Ala. 2006. "Muhammad's Social Justice or Muslim Cant?: Langdellianism and the Failures of Islamic Finance." Cornell International Law Journal 40(1), Columbia Public Law Research Paper No. 06-116. 
and promise of, Islamic finance. What many critics do not realize is that the instability of conventional, debt-based, finance has been criticized by many Western scholars who are quite innocent of Islamic finance or of the Shari'ah. Starting with Irving Fisher in the 1930s, many have noted how a profit-loss sharing system would produce a more stable economic system. Well-known economists, such as Willem H. Buiter, ${ }^{132}$ have argued that the world has too much leverage and too little equity, while the question posed by Luigi Zingales in his Presidential address to the American Finance Association was "Does Finance benefit Society."133 The alternative faith-based proposal of Islamic finance is to share both profits and losses. As Timur Kuran, an unsympathetic observer, notes in the context of Islamic finance in Egypt:

Having suggested that in its present form Islamic banking would not solve any of Egypt's pressing economic problems, let me acknowledge that Islamic banks might bring benefits by abiding by their stated mode of operation. The charters of Islamic banks instruct them to lend on the basis of "profit and loss sharing" rather than for a fixed return. ${ }^{134}$

The concept of profit/loss sharing has broad appeal, even outside of Islamic finance; Martin Weitzman ${ }^{135}$ of MIT, for example, has argued for a sharing economy.

The glaring defect of Islamic finance as it exists is that the practical implementation of profit/loss-sharing arrangements remains fairly limited. Furthermore, there seem to be no realistic prospects of a change toward equity instead of debt. Even though the returns to equity

132 Buiter, Willem H. and Rahbari, Ebrahim, 2015. "Why Economists (and Economies) Should Love Islamic Finance." Journal of King Abdulaziz University: Islamic Economics 28(1). Retrieved from https://ssrn.com/abstract=3065269.

133 Zingales, L. 2015. "Does Finance Benefit Society?” Journal of Finance 70(4), 13271363.

${ }^{134}$ Worstall, Tim. March 16, 2013. "There's Nothing Wrong With Islamic Finance as Long as It Really Is Islamic Finance." Forbes, https://www.forbes.com/sites/timworstall/ 2013/03/16/theres-nothing-wrong-with-islamic-finance-as-long-as-it-really-is-islamicfinance/\#53e598cb3e $2 b$.

${ }^{135}$ Weitzman M.L., Kruse D.L. 1990. "Profit Sharing and Productivity." In Blinder AS Paying for Productivity: A Look at the Evidence. Washington, DC: Brookings Institution, 95-142. 
(profit/loss-based) are clearly very much higher than that of bonds (interest based) in the long-run, Islamic finance has simply not risen to the challenge of realizing this long-run potential. This sloth is inexplicable in view of the Quranic warning that usury will bring war upon those who practice it:

O you who believe, fear Allah and give up what remains due to you of interest if you are indeed believers. And if you do not, then be warned of war (against you) by Allah and His Messenger, while if you repent you shall have your capital. Do not do wrong and you shall not be wronged.

(Quran 2:278-279)

If the Islamic finance industry and government regulators address the concerns and complaints made by a growing number of critics, including former champions ${ }^{136}$ of the industry, then there is still hope that the original ideals of Islam can provide a more equitable and stable economic system. In this case, faith has not sufficiently guided finance.

\section{BIBLIOGRAPHY}

Abbas, Mohammed. "Shortage of Scholars Troubles Islamic Banking." The New York Times, 2 February 2008. https://www.nytimes.com/2008/01/ 22/business/worldbusiness/22iht-bank.4.9412578.html.

Abdel-Khaleq, Ayman, and Christopher Richardson. "New Horizons for Islamic Securities: Emerging Trends in Sukuk Offerings." Chicago Journal of International Law 7, no. 2 (2007): 409-413.

136 Saleem, Muhammad. 2006. Islamic Banking-A $\$ 300$ Billion Deception: Observations and Arguments on Riba (Interest or Usury), Islamic Banking Practices, Venture Capital and Enlightenment. Bloomington: Xlibris Corporation.

I tell you, truthfully and without pretense, ... that we went beyond choosing the "bank" label [in "Islamic Banking"], to the point of adopting its central essence ... Consequently, we failed to give our financial institutions any characteristics beyond simple financial intermediation. This is accomplished through Islamic banks' favorite investment modes that are essentially a hybrid between loans and investment; which hybrid carries most of the characteristics of usurious loans....

Kamel, Saleh. 1996. (founder of Dallah al-Baraka group, acceptance speech for the Islamic Development Bank prize in Islamic Banking) quoted in El-Gamal, Mahmoud A. 2003. "Interest' and the Paradox of Contemporary Islamic Law and Finance," Fordham International Law Journal 27(1), Article 6, https://pdfs.semanticscholar.org/8cb7/ 0cc8baaf91 lad52f932205al722f76e3f049.pdf. 
Abdullah, Atikullah Hj. "The Elements of Qimar (Wagering) and Gharar (Uncertainty) in the Contract of Insurance Revisited," 2013. https://ibtra.com/ pdf/journal/v9_n2_article5.pdf.

Ahmad, Shaikh Mahmud. "Judaism and Interest." Islamic Studies 20, no. 1 (1981): 47-82.

Al-Hamdani, Khaled. al-Nizam al-Masrafi fi al-Dawlah al-Islamiyah (The Banking System in the Islamic State), 2000.

Alharbi, Ahmad. "Development of Islamic Finance in Europe and North America: Opportunities and Challenges." International Journal of Islamic Economics and Finance Studies 2, no. 3 (2016): 109-110.

Arberry, Arthur John. The Koran Interpreted: A Translation. New York: Simon and Schuster, 1996.

Archer, Simon, and Rifaat Abdel Karim. Islamic Finance: Growth and Innovation. London: Euromoney Books, 2002.

Ayub, Muhammad. Understanding Islamic Finance, 58. West Sussex: Wiley, 2007. Retrieved 30 August 2018.

Azhar, Rauf. Economies of an Islamic Economy, Themes in Islamic Studies, Vol. 6, 15 November 2009. https://doi.org/10.1163/ej.9789004179370.i-470.

Aziz, Zeti A. "Enhancing Interlinkages and Opportunities: The Role of Islamic Finance." Islamic Finance: Global Trends and Challenges 18 (2008): 5-7.

Azmat, Saad, A. S. M. Sohel Azad, Hamza Ghaffar, and Ishaq Bhatti. "Why Interest Free Islamic Banking Is Not Free from Interest?” 2015. https:// www.deakin.edu.au/_data/assets/pdf_file/0003/392295/islamic-bankingnot-free-from-interest-Azmat-Azad-Ghaffar-and-Bhatti.pdf.

Bacha, Obiyathulla I. "Adapting Mudarabah Financing to Contemporary Realities: A Proposed Financing Structure." INCEIF the Global University in Islamic Finance, 1997. https://mpra.ub.uni-muenchen.de/12732/1/ MPRA_paper_12732.pdf.

Balz, Kilian. "Islamic Finance for European Muslims: The Diversity Management of Shari'ah-Compliant Transactions." Chicago Journal of International Law 7, no. 2 (2007): 551.

Barreh, Ismail. "Scholar Shortage Threatens Islamic Financing Industry." MuslimLink, https://muslimlink.ca/islamic-finance/scholar-shortagethreatens-islamic-financing-industry.

Box, Tamara, and Mohammed Asaria. "Islamic Finance Market Turns to Securitization." International Financial Law Review 24 (2005): 21.

Buiter, Willem H., and Ebrahim Rahbari. "Why Economists (and Economies) Should Love Islamic Finance." Journal of King Abdulaziz University: Islamic Economics 28, no. I (2015). Retrieved from https://ssrn.com/abstract= 3065269.

Canada Islamic Finance Outlook 2016. Toronto Financial Service Alliance, IFSB Working Paper on Financial Consumer Protection In Islamic Finance. 
Chachi, Abdelkader. "Origin and Development of Commercial and Islamic Banking Operations." Journal of King Abdulaziz University: Islamic Economics 18, no. 2 (2005 A.D/1426 A.H): 3-25.

Dar, Humayon A., and John R. Presley. "Lack of Profit Loss Sharing in Islamic Banking: Management and Control Imbalances." International Journal of Islamic Financial Services 2, no. 2 (2000): 3-18.

di Mauro, Filippo, Pierluigi Caristi, Stéphane Couderc, Angela Di Maria, Lauren Ho, Baljeet Kaur Grewal, Sergio Masciantonio, Steven R. G. Ongena, Sajjad Zaheer. "Islamic Finance in Europe." ECB Occasional Paper No. 146. 15 April 2013. Retrieved from https://ssrn.com/abstract=2251204.

Domat, Chloe. "Towards Standards in Islamic Finance." Global Finance, 2018. https://www.gfmag.com/magazine/march-2018/toward-global-islamicfinance-standard.

El-Gamal, Mahmoud A. "'Interest' and the Paradox of Contemporary Islamic Law and Finance." Fordham International Law Journal 27, no. 1 (2003): Article 6. https://pdfs.semanticscholar.org/8cb7/ 0cc8baaf9l lad52f932205al722f76e3f049.pdf.

El-Gamal, Mahmoud A. Islamic Finance: Law, Economics and Practice. Cambridge: Cambridge University Press, 2006.

El-Ghattis, Nedal. "Islamic Banking's Role in Economic Development: Future Outlook." Retrieved from https://pdfs.semanticscholar.org/cfc6/ 6f09435a5445c2cadd2d18937823635c5d3d.pdf.

El Qorchi, Mohammed. "Islamic Finance Gears Up." Finance and Development 42 , no. 4 (2005): 46.

European Central Bank. "Islamic Finance in Europe," (Occasional Paper Series, No. 146, June 2013). Retrieved from https://www.ecb.europa.eu/pub/pdf/ scpops/ecbocpl46.pdf.

European Council for Ifta' and Research and the Conference of the League of Shari'ah Scholars of North America, "Permissibility of Conventional Mortgage Under Necessity." Fourth Ordinary Session (27-31 October 1999) Resolution 2/4-https://eshaykh.com/halal_haram/permissibility-of-conventionalmortgage-under-necessity/ and http://www.islamicmortgages.co.uk/index. php?id=259.

Fadel, Mohammad Riba. "Efficiency, and Prudential Regulation: Preliminary Thoughts." Wisconsin International Law Journal 25, no. 4 (Forthcoming): 656.

Farook, Sayd Zubair, and Mohammad Omar Farooq. "Shariah Governance, Expertise and Profession: Educational Challenges in Islamic Finance." ISRA International Journal of Islamic Finance 5, no. l (2013): 137-160.

Farooq, Mohammad Omar. "Stipulation of Excess in Understanding and Misunderstanding Riba: The Al-Jassas Link." Arab Law Quarterly 21, no. 4 (2007): 285-316. 
Farooq, Mohammad Omar. "Riba, Interest and Six Hadiths: Do We Have a Definition or a Conundrum?" Review of Islamic Economics 13, no. 1 (27 December 2009): 105-141.

Ferruelo, Elizabeth. "Why Socially Responsible Investing and Islamic Finance is on the Rise." Forbes, 2012. https://www.forbes.com/sites/ashoka/2012/ $11 / 01 /$ why-there-is-high-growth-potential-in-the-nexus-between-sociallyresponsible-investing-and-islamic-finance/\#5813dab0e3fl.

Ha, Tu Thanh. "RCMP Charge Missing Toronto Financier with \$4.3-Million Mortgage Fraud." The Globe and Mail, 2014. https://www.theglobeandmail. $\mathrm{com} /$ news/national/rcmp-charge-missing-toronto-financier-with-43-millionmortgage-fraud/articlel6972349/.

Hamoudi, Haider Ala. 2006. "Muhammad's Social Justice or Muslim Cant?: Langdellianism and the Failures of Islamic Finance." Cornell International Law Journal 40, no. 1 (2006). Columbia Public Law Research Paper No. 06-116.

Hanif, Muhammad. "Differences and Similarities in Islamic and Conventional Banking." International Journal of Business and Social Sciences 2, no. 2 (2014): 26.

Hasan, Zulkifli. "Demystifying the Myth of Shortage of Shari'ah Scholars," 2012. https://zulkiflihasan.wordpress.com/2012/03/02/demystifyingthe-myth-of-shortage-of-shariah-scholars- $2 /$.

Hassan, M. K. and M. F. Dicle. "Basel II and Corporate Governance in Islamic Banks." In Integrating Islamic Finance into the Mainstream: Regulation, Standardization and Transparency, edited by S. N. Ali, 31-50. Cambridge, MA: Islamic Finance Project, Harvard Law School, 2007.

Hayat, Usman. "Islamic Finance and Socially Responsible Investing." CFA Institute News, 2013. https://www.cfainstitute.org/-/media/documents/article/ cfa-magazine /2013/cfm-v24-n2-2.ashx.

Hussain, Mumtaz, Asghar Shahmoradi, and Rima Turk. "An Overview of Islamic Finance.” IMF Working Paper, 2015. https://www.imf.org/external/pubs/ $\mathrm{ft} / \mathrm{wp} / 2015 / \mathrm{wp} 15120 . \mathrm{pdf}$.

Iqbal, Zamir, and Abbas Mirakhor. An Introduction to Islamic Finance: Theory and Practice, 2nd ed. Asia: Wiley, 2011.

Islamic Finance Working Group. Toronto Financial Service Alliance, 2010. Retrieved from http://www.tfsa.ca/resources/pdf/TFSA_IFWG_Prelim_ Report_May14_2010_final_2.pdf.

Issawi, C. The Economic History of the Middle East 1800-1914. Chicago: University of Chicago Press, 1966.

Jamaldeen, Faleel. "Seven Prohibited Industries in Islamic Financial Investments." https://www.dummies.com/personal-finance/islamic-finance/sevenprohibited-industries-in-islamic-financial-investments $/$. 
Kamali, M. H. "Source, Nature and Objectives of Shari'ah." Islamic Quarterly 33 (1989): 211-233.

Karasik, Theodore, Frederic Wehrey, and Steven Strom. "Islamic Finance in a Global Context: Opportunities and Challenges." Chicago Journal of International Law 7, no. 2 (2006): 379.

Khan, F. How “'Islamic' Is Islamic Banking?” Journal of Economic Behavior \& Organization 76, no. 3 (2010): 818.

Khan, Sheema. "It's Time to Take Interest in Islamic Financing." The Globe and Mail, 7 April 2008. https://www.theglobeandmail.com/opinion/its-time-totake-interest-in-islamic-financing/article22501330/.

Koch, Michael. "Sukuk vs Conventional Bonds: A Study into the Performance of Islamic Bonds." https://pdfs.semanticscholar.org/e830/ 9e00e7de945a3e6lae4447208ee7a02e3b0f.pdf.

Kuran, Timur. Islam and Mammon: The Economic Predicaments of Islamism. Princeton: Princeton University Press, 2004.

Kutty, Faisal. "The Myth and Reality of 'Shari'a Courts' in Canada: A Delayed Opportunity for the Indigenization of Islamic Legal Rulings." University of St. Thomas Law Journal 7 (2010): 559.

Kutty, Faisal. "The Kutty 'Islamic Law' Flowchart,” 24 September 2014. http:// www.islamiclawflowchart/.

Labib, S. "Capitalism in Medieval Islam." Journal of Economic History 29, no. 1 (March 1969): 79-140.

Langah, Waseem Ahmad. Islamic Banking in the UK: Challenges and Opportunities, 25 February 2009. Retrieved from https://ssrn.com/abstract=1349170.

Maljichi, Drita N. "Islamic Financial Markets and Institutions." Vizione 21 (2014): 291-292.

Marais, Richard. "Don't Call It Interest.” Forbes, 2007. https://www.forbes. com/forbes /2007/0723/122.html\#242132b74354.

Mayyasi, Alex. "Of Money and Morals." Aeon, 2017. Retrieved from https:// aeon.co/essays/how-did-usury-stop-being-a-sin-and-become-respectablefinance.

Murababah Trade Financing. Maldives Islamic Bank. http://www.mib.com.mv/ pages/view/murabahah-trade-financing.

Nasser, Shanifa. "Muslim Mortgage Kingpin Led Investigators on 'Treasure Hunt' for Missing Gold: Crown.” CBC News, 2017. https://www.cbc. $\mathrm{ca} /$ news/canada/toronto/omar-kalair-muslim-madoff-shariah-mortgages-1. 4390002 .

Nehad, A., and Khanfar, A. "A Critical Analysis of the Concept of Gharar in Islamic Financial Contracts: Different Perspectives." Journal of Economic Cooperation and Development 37 no. 1 (2016): 1-24. http://www.sesric.org/ pdf.php?file=ART14103001-2.pdf. 
Nienhaus, Volker. "IFSB Working Paper on Financial Consumer Protection in Islamic Finance. IFSB Working Paper Series." Islamic Financial Services Board, 2015.

Nizami, Shah M. “Islamic Finance: The United Kingdom's Drive to Become the Global Islamic Finance Hub and the United States' Irrational Indifference to Islamic Finance." Suffolk Transnational Law Review 34, no. l (2011): 219.

Oseni, Umar A., Abu Umar Faruq Ahmad, and M. Kabir Hassan. "The Legal Implications of 'Fatwā Shopping' in the Islamic Finance Industry." Arab Law Quarterly 30, no. 2 (2016): 102-137.

Pasha, Shaheen, and Cameron French. "Canada Bankruptcy May Hurt Islamic Finance in N. America." Reuters, 2011. https://www.reuters.com/article/ canada-islamic-bankruptcy-idUSL5E7MT3KY20111205.

Pock, Alexander. Strategic Management in Islamic Finance. Berlin: Springer Science \& Business Media, 2007.

Qadri, Shahzad. "Islamic Banking-An Introduction." Business Law Today 17, no. 6 (2007): 59.

Qazi, Irfan. "Murabaha Financing vs. Lending on Interest," 2008. Retrieved from https://ssrn.com/abstract=180365l or https://doi.org/10.2139/ssrn. 1803651 .

Rammal, Hussain Gulzar. "Financing Through Musharaka: Principles and Application." Business Quest, 2004. Retrieved from https://ssrn.com/abstract= 1442430.

Reda, Ayman. Prophecy, Piety, and Profits: A Conceptual and Comparative History of Islamic Economic Thought. New York: Palgrave Macmillan, 2018.

Richardson, Christopher F. "Islamic Finance Opportunities in the Oil and Gas Sector: An Introduction to an Emerging Field.” Texas International Law Journal 42 (2006): 119-123.

Salah al-Sawi. A Polite Reconsideration of the Fatwa Permitting InterestBased Mortgages for Buying Homes in Western Societies, translated by Usama Hasan, 21 June 2001. https://unityl.files.wordpress.com/2009/06/ analysis-of-fatwas-on-mortgages.pdf.

Saleem, Muhammad. Islamic Banking-A \$300 Billion Deception: Observations and Arguments on Riba (Interest or Usury), Islamic Banking Practices, Venture Capital and Enlightenment. Bloomington: Xlibris Corporation, 2006.

Schoon, Natalie, and Julinda Nuri. "Comparative Financial Systems in Judaism, Christianity and Islam: The Case of Interest," 2012. Retrieved from https:// ssrn.com/abstract=2126503 or http://dx.doi.org/10.2139/ssrn.2126503.

Seputis, Jasmine. "2 Men Defrauded Shariah-Compliant Mortgage-Holders of Millions of Dollars, Crown Tells Trial." CBC News, 2018. https://www.cbc. $\mathrm{ca} /$ news/canada/toronto/2-men-defrauded-shariah-compliant-mortgageholders-of-millions-of-dollars-crown-tells-trial-1.4867083. 
Seznec, Jean-François. "Ethics, Islamic Banking and the Global Financial Market." Fletcher Forum of World Affairs 23, no. 1 (1999): 161.

Shaikh, Salman Ahmed. "A Brief Review \& Introduction to Practiced Islamic Banking \& Finance," 14 January 2010. Retrieved from https://ssrn.com/ abstract $=1536943$ or https://doi.org/10.2139/ssrn.1536943.

Shaikh, Salman Ahmed. "A Critical Analysis of Mudarabah \& A New Approach to Equity Financing in Islamic Finance." Journal of Islamic Banking o Finance (2011). Retrieved from https://ssrn.com/abstract=1930173.

Staff Writer. "Islamic Finance Assets Forecast to be Worth $\$ 3.2$ trn by 2020." Arabian Business, 7 August 2016. https://www.arabianbusiness.com/islamicfinance-assets-forecast-be-worth-3-2trn-by-2020-641156.html.

Statistics Canada. 2011 National Household Survey: Data Tables, 99-010X2011032. Ottawa, 1991.

Stubing, Darren. "Islamic Finance Held Back by Lack of Supervision, Liquidity." Global Finance, 2015. https://www.gfmag.com/magazine/may-2015/lacksupervision-liquidity-holding-back-islamic-finance.

Sweeney, Annie. "Guilty Plea in Fraud Scheme That Targeted Muslim community." The Chicago Tribune, 28 March 2011. https://www.chicagotribune. com/news/ct-xpm-2011-03-28-ct-met-muslim-fraud-guilty-20110328-story. html.

Terrell, Ron. "Islamic Banking: Financing Terrorism or Meeting Economic Demand?" (thesis). Naval PostGraduate College, 2007 https://apps.dtic.mil/ dtic/tr/fulltext/u2/a475770.pdf.

Thomas, Abdulkader, Stella Cox, and Bryan Kraty. Structuring Islamic Finance Transactions. Linnius, 2005.

Thomson Reuters. Canada Islamic Finance Outlook 2016 at 58, 2015. http:// www.tfsa.ca/storage/reports/Canada_Islamic_Finance_2016.pdf.

Uddin, Md Akther. Principles of Islamic Finance: Probibition of Riba, Gharar and Maysir. Kuala Lumpur, Malaysia: INCEIF, 2015. https://mpra.ub.unimuenchen.de/67711/1/MPRA_paper_67711.pdf.

Udovitch, A. "Bankers Without Banks: Commerce, Banking and Society in the Islamic World of the Middle-Ages." In The Dawn of Modern Banking, edited by the Centre for Medieval and Renaissance Studies. University of California: Los Angeles, 1979.

Waemustafa, W. "Theory of Gharar and Its Interpretation of Risk and Uncertainty from the Perspectives of Authentic Hadith and the Holy Quran: Review of Literatures," 2015. http://repo.uum.edu.my/18860/1/Wae_gharar.pdf.

Wafik, Grais and Matteo Pellegrini. Corporate Governance and Shariah Compliance in Institutions Offering Islamic Financial Services. 2006. World Bank Policy Research Working Paper No. 4054.

Warde, Ibrahim. "The Revitalization of Islamic Profit-and-Loss Sharing." Proceedings of the Third Harvard University Forum on Islamic Finance: Local 
Challenges, Global Opportunities, 199-211. Cambridge, MA: Center for Middle Eastern Studies, Harvard University, 1999. http://ifpprogram.com/ $\operatorname{login} /$ view_pdf/?file=The $\% 20$ Revitalization $\% 20$ of $\% 20$ Islamic\%20Profit-andloss\%20Sharing.pdf\&type $=$ Project_Publication.

Weber, Max. Economy and Society. Berkeley, CA: University of California Press, 1979.

Weitzman M. L., D. L. Kruse. "Profit Sharing and Productivity." In Blinder AS Paying for Productivity: A Look at the Evidence, 95-142. Washington, DC: Brookings Institution, 1990.

Wilson, Rodney. Capital Flight Through Islamic Managed Funds. Edinburgh: Edinburgh University Press, 2004.

Zaher, Tarek S., and M. Kabir Hassan. "A Comparative Literature Survey of Islamic Finance and Banking." Financial Markets, Institutions \& Instruments 10, no. 4 (2001): 155-199.

Zaman, Arshad. "Sayyid Abu'l A'la Maududi on Islamic Economics: A Review Article." Islamic Studies 50, no. 3-4 (2011): 303-323. Retrieved from https://ssrn.com/abstract=2225711.

Zingales, L. "Does Finance Benefit Society?" Journal of Finance 70, no. 4 (2015): 1327-1363.

Open Access This chapter is licensed under the terms of the Creative Commons Attribution 4.0 International License (http://creativecommons.org/licenses/ by $/ 4.0 /)$, which permits use, sharing, adaptation, distribution and reproduction in any medium or format, as long as you give appropriate credit to the original author(s) and the source, provide a link to the Creative Commons license and indicate if changes were made.

The images or other third party material in this chapter are included in the chapter's Creative Commons license, unless indicated otherwise in a credit line to the material. If material is not included in the chapter's Creative Commons license and your intended use is not permitted by statutory regulation or exceeds the permitted use, you will need to obtain permission directly from the copyright holder.

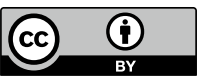

